SERI/STR-231-2496

UC Category: 61c

DE85000518

\title{
Research and Development of Shallow Algal Mass Culture Systems for the Production of Oils
}

\section{A Subcontract Report}

Edward A. Laws

University of Hawaii

Honolulu, Hawaii

October 1984

Prepared under Subcontract No. XK-3-03136

SERI Technical Monitor: Robins Mclntosh

Solar Energy Research Institute

A Division of Midwest Research Institute

1617 Cole Boulevard

Golden, Colorado 80401

Prepared for the

U.S. Department of Energy

Contract No. DE-AC02-83CH10093 


\author{
Printed in the United States of America \\ Available from: \\ National Technical Information Service \\ U.S. Department of Commerce \\ 5285 Port Royal Road \\ Springfield, VA 22161 \\ Price: \\ Microfiche A01 \\ Printed Copy A04
}

\begin{abstract}
NOTICE
This report was prepared as an account of work sponsored by the United States Government. Neither the United States nor the United States Department of Energy, nor any of their employees, nor any of their contractors, subcontractors, or their employees, makes any warranty, express or implied, or assumes any legal liability or responsibility for the accuracy, completeness or usefulness of any information, apparatus, product or process disclosed, or represents that its use would not infringe privately owned rights.
\end{abstract}




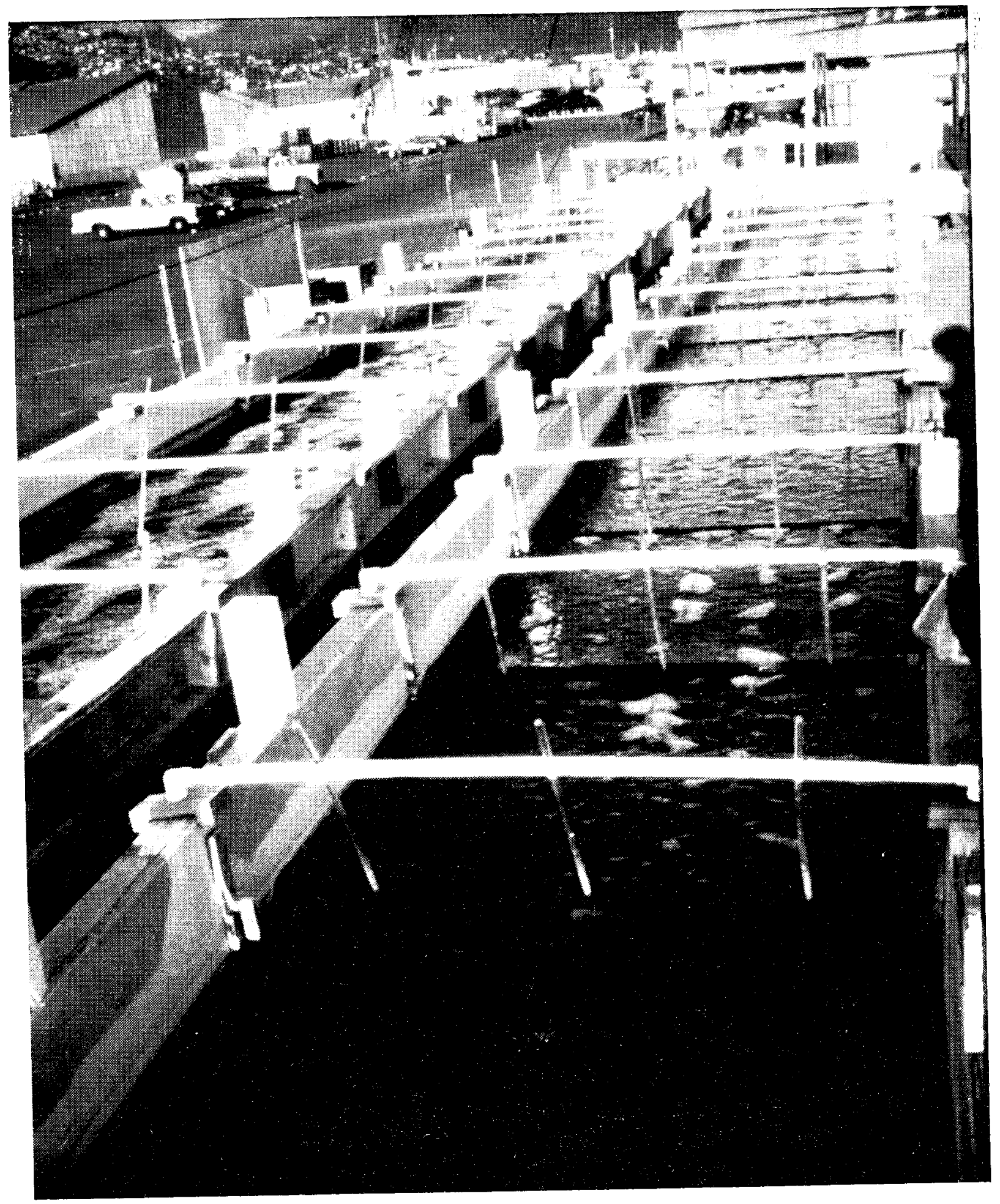

The $48-\mathrm{m}^{2}$ outdoor raceway system showing installed foils 


\section{FOREWORD}

This report is the final report for FY 1984. The work was performed under subcontract to SERI with funds provided by the Biomass Energy Technology Division of the U.S. Department of Energy under a program to investigate the mass culture of microalgae as a source of renewable fuels.

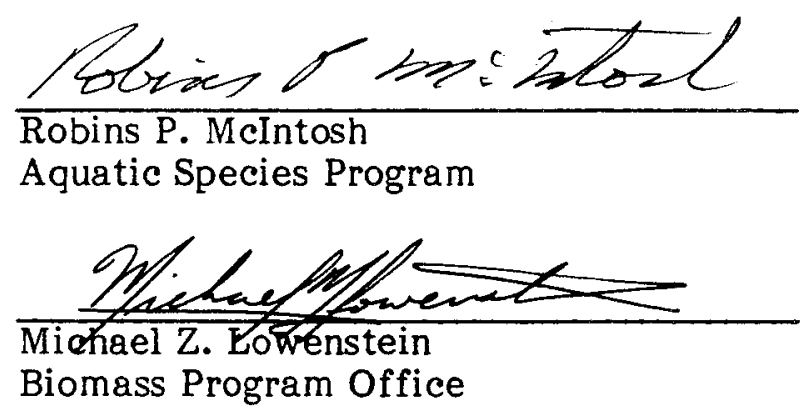

Approved for the

SOLAR ENERGY RESEARCH INSTITUTE

$\frac{\text { ftanduy thall }}{\text { Stapley R. Bull, Director }}$

Solar Fuels Research Division 
SUMMARY

\section{objective}

The objective of this project was to determine whether microalgae could be grown successfully in a shallow outdoor flume without temperature control, to determine the yields which could be achieved from such a system, and to evaluate the merits of such mass culture for the purposes of energy production from an economic and energetic standpoint.

\section{Discussion}

A shallow flume system for the mass culture of microalgae has been developed and constructed by the university of Hawaii. Briefly, the system concept includes shallow channels circulated at a high flow rate containing very dense algal cultures. Airlift pumps, restricted within $15 \mathrm{~cm}$ PVC pipes, are used for recirculation and gas exchange. A major contribution of the Hawaii project has been the development of a system that introduces ordered vertical mixing into the culture as a byproduct of stream flow. small foils, similar in design to airplane wings, are suspended in the flowstream at a relatively high angle of attack. Vortices are generated at the tips of each of these foils and are propagated downstream. Arrays of foils are positioned every $1.2 \mathrm{~m}$ along the culture flume. observation of the vortex rotation rates have indicated that cells are exposed to a light-dark cycle time of 1 to 2 seconds in this mixing regime. This light-dark cycling avoids prolonged exposure of the cells to bright light and associated low photosynthetic efficiencies. Productivity in a system employing the foils is about 2.2 times the productivity in the same system without foils.

A major accomplishment of the past nine months' work was the identification of a microalgal species which can be grown in the system on a 12-month basis without temperature control. The most promising species identified to date is a strain of Platymonas sp.. This strain grows rapidly at temperatures from 20 to $34^{\circ} \mathrm{C}$, and at salinities from 15 to $35 \%$ oo. Neither the lower temperature limit nor the lower salinity limit of the strain are known at this time. A factorial experiment designed to determine optimum growth conditions indicated that the optimlim culture derth was $10 \mathrm{~cm}$, the optimum $\mathrm{pH}$ about 7.5, and the optimum flow rite about $30 \mathrm{~cm} / \mathrm{sec}$. A major discovery was that diluting the culture every third day greatly enhanced production. In this dilulion moke daily yields averaged $46 \mathrm{~g} / \mathrm{m}^{2}$ ash-free dry weight (AFW) (V) a one-nonth period, and photosynthetic efficiencies avalural $11 \%$ (bascd on visible light energy). The former figure I" ov $1 \mathrm{w}$ ice the hest long-term yields achieved in microalgal

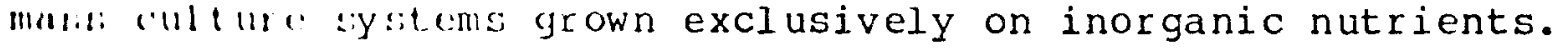




\section{Conclusions}

An economic analysis of the shallow outdoor flume system indicated that if photosynthetic efficiencies of $11 \%$ can be maintained, then energy from algal biomass will be cost competitive with crude oil at a crude oil price of $\$ 57$ per barrel. This calculation assumes that the microalgae are grown without the benefit of temperature controls, a clearly achievable goal if Rlatymonas or a similar eurythermal species is the cultured organism. Use of temperature controls to grow a less thermophilic species such as Phaeodactylum tricornutum would more than double production costs. An energetic analysis of the flume system inaicated that the major energy inputs were the energy required to provide fixed nitrogen, the energy required to operate the airlift pumps, and the energy required for harvesting and processing. However, if the entire energy content of the microalgae is utilized, the energy output of the system is over four times the energy input. 
1.0 Introduction

1.1. Historical Background

1.2 Theoretical Background

2.0 Materials and Methods

2. I The culture System

2.2 Analytical Data

3.0 Results

3.1 Task I: Screening of Candidate species

3.2 Task II: yield Optimization of

Promising Species in Shallow Dutdoor Flumes

3.3 Fractional Factorial Experiments with

Platymonas

3.4 Nutrient Starvation Studies with platymonas 23

3.5 Long Term production Run with platymonas 23

3.6 Efforts to Grow Other Species 35

3.7 Task III: Analysis of Promising culture 36 Management strategies

4.0 References

5.0 Appendix 
Page

1-1 Design of a single foil indicating mechanism of 5 vortex production

1-2 Positioning of individual foils in foil array. Lower figure indicates positioning of array in the flume. D is the depth of the water. Arrows indicate rotational direction of vortices

2-1 Perspective of algal production flume showing location of lift box, drain box, and airlift system

2-2 Cross section of flume modules indicating positioning of airlift and $\mathrm{CO}_{2}$ feed

2-3 Detail of recirculation and airlift system 10

2-4 Schematic of seawater supply system and algal 12 storage tank

3-1 Growth of four species of marine microalgae at 16 $34^{\circ} \mathrm{C}$ in IMR medium

3-2 Platymonas production as a function of $\mathrm{pH} \quad 18$ and dilution rate. Curved lines are fit of $\mathrm{Eq}$. I to data

3-3 C/N ratios during period of nutrient starvation 24 in Platymonas culture

3-4 Lipid content of Platymonas cultures during 25 nutrient starvation study

3-5 Long term Platymonas production and photosynthetic efficiency results in $48 \mathrm{~m}^{2}$ flume. Data points are six-day running means 


\section{LIST OF TABLES}

Page

2-I Elume specifications. 8

3-1 Log phase growth rates (doublings per day) of 15 four strains of microalgae which grew at temperatures of $32^{\circ} \mathrm{C}$ and $34^{\circ} \mathrm{C}$.

3-2 Proauction results in $9.2 \mathrm{~m}^{2}$ flumes operated under identical conditions. Culture depth was $10 \mathrm{~cm}$ and dilution rate $50 \%$ per day in all cases. Production values are daily means $\left(\mathrm{gC} \mathrm{m}^{-2}\right.$ ) over a one-week period.

3-3 Production results in $9.2 \mathrm{~m}^{2}$ flumes run at a depth of $10 \mathrm{~cm}$ and dilution rate of $50 \%$ per day. $\mathrm{pH}$ was controlled at 7.5 either by $\mathrm{CO}_{2}$ bubbling or addition of $\mathrm{HCl}$. Results are average daily proauction rates $\left(\mathrm{gC}^{-2}\right)$ over the indicated number of days.

3-4 First-order factorial production results in

$9.2 \mathrm{~m}^{2}$ flumes with Platymonas. Culture depth was $10 \mathrm{~cm}$, dilution rate $50 \%$ per day. Results are daily production rates ( $\mathrm{gC}^{-2}$ ) averaged over a two-week period.

3-5 Compositional analysis of Platymonas cells at start of nutrient starvation experiment (in parentheses) and after 14 days of starvation.

3-6 Monthly means of solar radiation (PAR) and maximum 28 and minimum water temperatures in $48 \mathrm{~m}^{2}$ flume during January - May, 1984.

3-7 Mean particulate organic carbon and ash-free dry weight concentrations in the $48 \mathrm{~m}^{2}$ flume during three-day dilution cycle experiments. Units are $\mathrm{g} \mathrm{m}^{-3}$.

3-8 Summary of 1 ipid analyses on platymonas culture from $9.2 \mathrm{~m}^{2}$ flume during three-day dilution cycle. Lipid content expressed as $z$ of AFDW.

3-9 Production results from $9.2 \mathrm{~m}^{2}$ flumes operated at a $\mathrm{pH}$ of 7.5 and depth of $10 \mathrm{~cm}$ during April-May, 1984.

3-10 li:t imated costs associated with operation of a shallow algal mass culture facility cxprosicich on a per acre-year basis. 
Estimates based on operation of a 1000 acre facility (33).

3-11 Materials and energy inputs required to produce platymonas in shallow outdoor flume.

3-12 Annual energy balance for shallow algal mass culture system expressed on a per acre water surface area basis. Estimates based on operation of a 1000 acre facility (33). 
SECTION 1.0

INTRODUCTION

\section{I.I H ISTORI CAL BACKGROUND}

Microalgae are attractive as biomass producers because they generally exhibit higher yields and photosynthetic efficiencies than terrestrial plants. In addition, many species of microalgae produce high concentrations of intracellular oils as energy storage compounds. Microalgae are projected from laboratory scale experiments to be capable of producing over 100 barrels of liquid fuel per acre-year. Most pilot-scale mass culture systems, operated at depths of greater than $20 \mathrm{~cm}$, have shown peak average yields of around 15 dry ash free grams $\mathrm{m}^{-2} \mathrm{~d}^{-1}$. This project is based on the premise that operation at less than $15 \mathrm{~cm}$ depth will result in significantly higher productivities.

Research on this problem began at the University of Hawaii under SERI subcontract on February 15, 1980 under the title "Research, Development, and Demonstration of Algal Production Raceway (APR) Systems for the Production of Hydrocarbon Resources." Work during the first two and one-half years resulted in the collection of a great deal of laboratory data on the performance of Phaeodactylum tricornutum; the design, construction, and operation of one $48 \mathrm{~m}^{2}$ continuous flume; the development of predator control techniques and baseline performance characteristics for the flume; and the construction of four $9.2 \mathrm{~m}^{2}$ experimental flumes.

A major contribution of the project during these early years was the development of a system that introduced ordered vertical mixing into the culture as a by-product of stream flow. Small. foils, similar in design to airplane wings, were suspended in the flowstream at a relatively high angle of attack. Vortices were generated at the tips of each of these foils and were propagated downstream. Arrays of foils were positioned every $1.2 \mathrm{~m}$ along the culture flume. Observations of the vortex rotation rates indicated that cells were exposed to a light-dark cycle time of 1 to 2 seconds in this mixing regime. Productivity in the system employing the foils was increased by a factor of 2.2 over the productivity in the same system without foils.

During the 1982-83 funding period the four $9.2 \mathrm{~m}^{2}$ experimental flumes were operated in a factorial design experiment to determine the maximum sustainable biomass yields achievable with P. tricornutum cultured in shallow flume systems. Dilution rate and $\mathrm{CO}_{2}$ supply were found to be the most important system parameters. Maximum production was found to be about $25 \mathrm{~g}$ ashfree dry wt m-2 $\mathrm{d}^{-1}$. This production corresponded to a photosynthetic efficiency of 5.6\%. These figures were 50-1008 
better than the production rates achieved in earlier P. tricornutum cultures using conventional culture techniques. The results were found to be consistent with a theoretical model of the impact of the flashing light effect on algal mass culture production. This model predicted that at the typical irradiances in Hawaii, full utilization of the flashing light effect should enhance production by $70 \%$ to over $200 \%$. It was concluded that the use of foil arrays in the experimental flume created systematic vertical mixing on a time scale suitable for utilizing the flashing light effect. It was found that harvesting P. tricornutum cells could be accomplished straightforwardy by adding approximately $0.5 \mathrm{mM}$ NaOH to the culture. With this addition the cells rapidly flocculated and settled out with almost $100 \%$ efficiency.

Although high yields were achieved with P. tricornutum during this period of study, a serious problem with the use of P. tricornutum in outdoor algal cultures became apparent. P. tricornutum grows poorly if at all when temperatures exceed $25^{\circ} \mathrm{C}$. In parts of the U.S. best suited for algal mass culture growth, water temperatures during the summer months, the prime production season, will routinely exceed $25^{\circ} \mathrm{C}$. If the water were cooled in order to permit growth of $P$. tricornutum, the energy inputs to the system would exceed the energy produced. It therefore became obvious that strains of microalgae capable of growing in the temperature range $25-35^{\circ} \mathrm{C}$ would have to be identified, and their production capability in shallow outdoor mass culture systems determined. The primary goal of the past year's research was therefore to determine maximum sustainable biomass yields achievable with thermophilic species of marine microalgae cultured in outdoor shallow flume systems. Secondary goals were to l) gain an understanding of the mechanisms and conditions which lead to high productivity, photosynthetic efficiency, and lipid yield, and 2) analyze the effect on production of growing thermophilic strains during warm weather and $\mathrm{P}$. tricornutum during cooler weather as a means of minimizing biomass production costs. It was expected that these goals would be achieved through work on the following three tasks:

I Screening of candidate species in laboratory cultures I Yield optimization of promising species in outdoor flumes

II Analysis of promising culture management strategies

\section{2. 'THEORLI'I CAL BACKGROUND}

Il has: horn known for a number of years that the efficiency of light uilination by phytoplankton can be markedly increased by exposing the cel ls to alternating periods of light and dark (17). Mur acuntly, a number of investigators have explored this fhemomenum buth experimentally and theoretically (8-15). Although

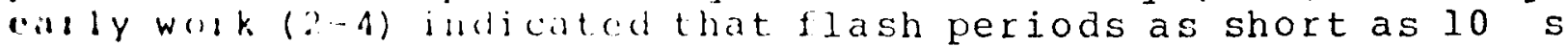
wel Harled lo take maximum acivantage of the flashing light 1110.1, it i:: now elcar that flash periods as long as 10-70 ms may : 111 in:ul in significant enhancements of photosynthetic 
efficiencies $(14,16)$, and Marra (13) has reported increases up to $87 \%$ in photosynthesis by simply modulating the irradiance on algal cells on a time scale ranging from minutes to hours. It seems reasonable to postulate that the physiological mechanisms responsible for these observed photosynthetic enhancements differ substantially over the vast range of time scales involved. However, regardless of the physiological mechanisms involved, it is clear that photosynthetic efficiencies may be enhanced by a factor of two or more by modulating or flashing the incident light on an appropriate time scale. For the case of flashing light, it is apparent that the maximum duration of the light pulse which produces the highest photosynthetic efficiency will be negatively correlated with light intensity at light intensities greater than or equal to $I_{K}$, the light intensity above which photosynthetic efficiency begins to decrease under constant illumination (17), and that the duration of the dark period must lie somewhere in the approximate range 0.1-10s (18).

A critical question in algal mass culture work is whether a physical mechanism exists for taking advantage of the flashing light effect in a practical way. As noted by phillips and Myers (14), "Any attempt to grow algae in sunlight will experience some gain by turbulence. The feasability of increasing the turbulence will depend upon the extent of the gain in growth as compared to the increased power requirements of stirring or pumping the suspension." Unfortunately, it does not appear that merely producing random turbulence is sufficient to take advantage of the flashing light effect to any significant degree in a mass culture system. Powell, Chaddock, and Dixon (15) reached this conclusion based on theoretical calculations, and Miller et al. (19) commented that, "Utilization of the flashing light effect for improvement of photosynthetic efficiency of dense algal cultures requires a nonrandom mixing pattern - one in which cells are exposed to regular sequences of light and darkness..."

In the past two types of experimental systems have been studied as possible means of utilizing the flashing light effect. A socalled Couette device was used by Miller et al. (19), Davis et al. (20), and Howell, Fredrickson, and Tsuchiya (2l). The Couette device consists of two concentric, circular cylinders, the inner of which can be rotated at a selected speed. The system is illuminated either from the outside or inside, and the culture is grown in the gap between the cylinders. The flow pattern in the culture medium is complex, but sufficiently nonrandom that a systematic flashing light effect is achieved. Howell, Fredrickson, and Tsuchiya (21) estimated the period of the light-dark cycles in their system to be about $40 \mathrm{msec}$. More recentiy, oswald et al. (22) and Shelef, Sabanas, and Oswald (23) have ciescribed a chemostat-type system called an algatron, which consists of a drum that is rotated about its vertical axis. The algal culture is contained within the drum as a film a few centimeters thick on the inside wall of the drum, and is retained against the wall by centrifugal force. A light source is mounted inside the drum, and a row of steel strips extending to withill 0.5-1.0 $\mathrm{mm}$ of the inside wall produces highly turbulent wat..:, 
which extend in spirals around the culture. The photosynthetic efficiencies which can be achieved with the couette device and algatron are on the order of 108 (17).

It seems unlikely that either the couette device or the algatron will prove to be a practical means of utilizing the flashing light effect. Both devices are mechanically complex, and the power requirements for operating them may well. offset any increase in production, both from a financial and an energetic standpoint. As noted by Fredrickson and Tsuchiya (17), "Clearly some device that is mechanically more simple than the foregoing devices is required." The mechanism we have devised to produce systematic vertical mixing in our flume is illustrated in Figures 1-1 and 1-2. The device consists of a series of foils similar in design to airplane wings placed across the flume. As water flows over and under these foils, a pressure difference is created as illustrated in Figure 1-1. At the tips of the foil, the flow of water from the high pressure region below the foil to the low pressure region above the foil creates a vortex off each tip of the foil. If the foils are properly spaced along a suitable supporting structure (Figure 1-2), the vortices on adjacent foils rotate in opposite directions and thus reinforce each other. The width of each foil and the gap between foils are equal to the depth of the culture, so that circular vortices created by the foils effectively mix the culture from top to bottom (Figure 12). The system of vortices with rotational axes parallel to the direction of flow produces the sort of systematic mixing necessary to produce the flashing light effect.

\section{SECTION 2.0}

\section{MATERIALS AND METHODS}

\subsection{THE CULTURE SYSTEM}

The flumes utilized in our studies consisted of one $48 \mathrm{~m}^{2}$ continuous flume and four $9.2 \mathrm{~m}^{2}$ continuous flumes. The $48 \mathrm{~m}^{2}$ flume is illustrated in Figure 2-1, and specifications for the $48 \mathrm{~m}^{2}$ flume appear in Table 2-1. The flume is of a modular construction. The base channel module is a $1.2 \times 2.4 \mathrm{~m}$ molded fiberglass trough with $10 \mathrm{~cm}$ sides. The sides are raised an additional $23 \mathrm{~cm}$ with a plywood extension, coated with acrylic resin (Figure 2-2). All seams are covered with fiberglass cloth and resin. The channel modules are reinforced with split $7.5 \mathrm{~cm}$ diameter polyvinyl chloride (PVC) pipe, and are mounted on $5 \times 10$ ('II wooden rails supported by concrete blocks.

In acicition to the channel modules, there are two end-box modules and a luxning box. One end-box serves as a drain box, the other a:1 a lift hox, and they are connected by three recirculation lif'e: with airlifts. The drain box (Figure 2-2) includes a small 1.)- (m) dor. : :ump to provide for even flow. The airlifts dicharge diccel $1 \mathrm{Y}$ onto the level surface of the flume in the $1 \mathrm{ift}$ box ("Nigur, 2-2). The recirculation pipes (Figure 2-3) are $15 \mathrm{~cm}$ 


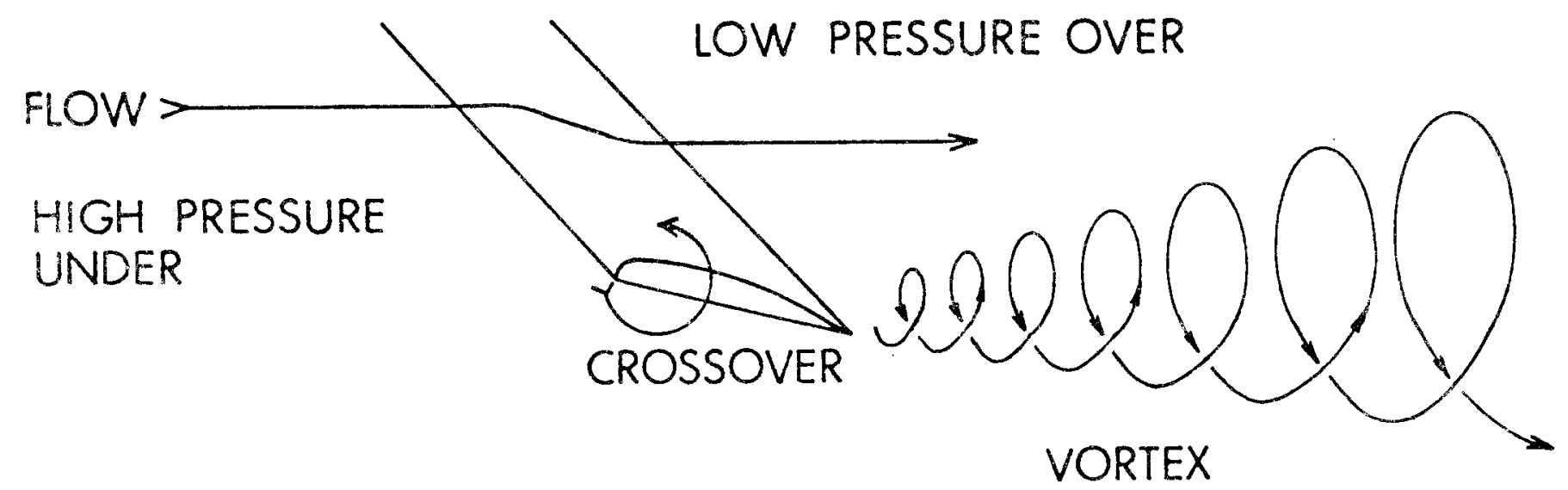

Ficure 1-1. Design of a single foil indicating mechanism of vortex production 

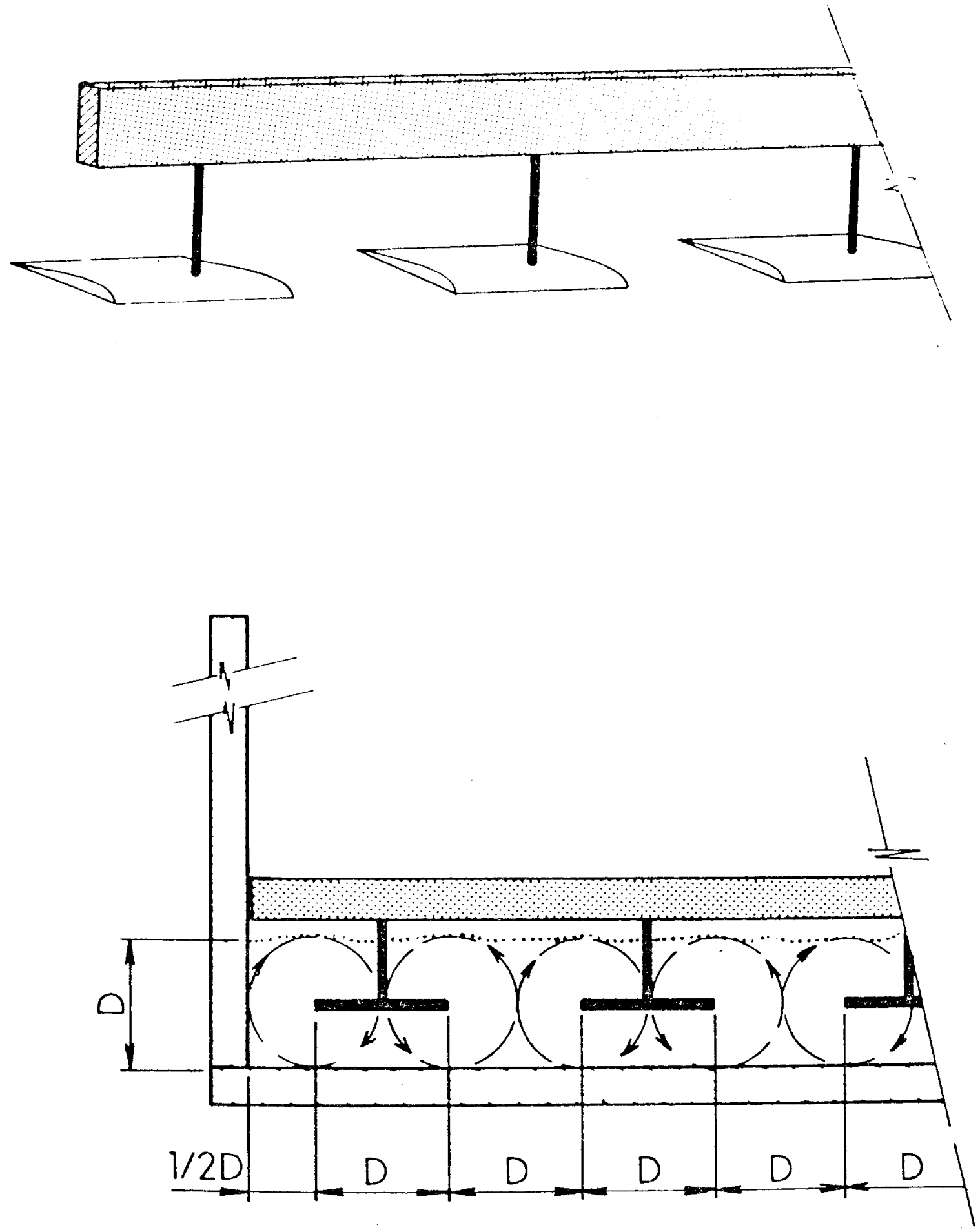

Figure 1-2. Positioning of individual foils in foil array, Lower figure indicates positioning of arroy in the flume, D is the depth of the water. Arrows indicate rotational direction of vortices 


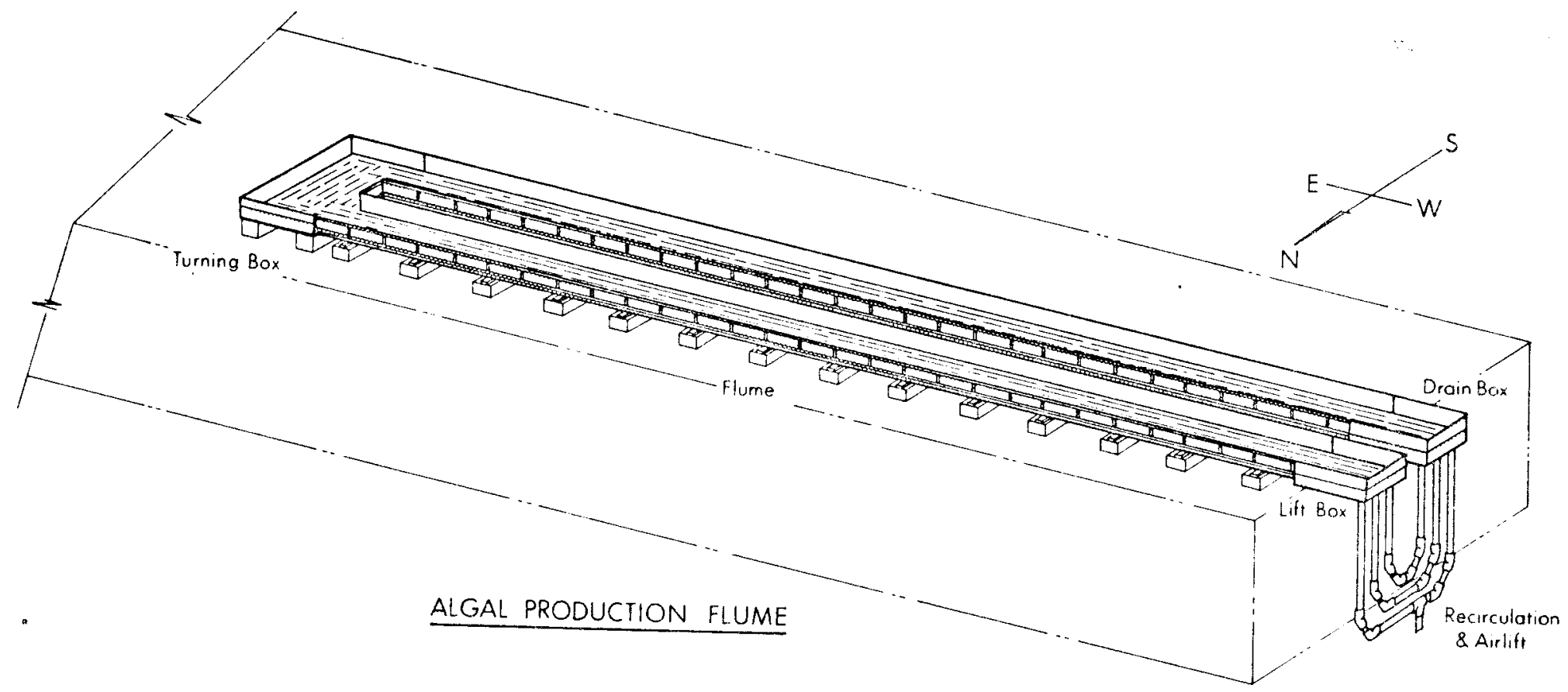

Figure 2-1. Perspective of algal production flume showing system 
Cons* ruction

Centerline channel length Area

Depth range

Operating depth

Volume at operating depth Flow rate

Slope

\section{Flume Specifications}

Modular: 1 liftbox module

1 turning box/heat exchanger

1 drainbox

14 channe1 modules

3 recirculation pipes/airlifts

$37.2 \mathrm{~m}$
$48.39 \mathrm{~m}^{2}$

$5-28 \mathrm{~cm}$

$7.75 \mathrm{~cm}$ (standard deviation $0.74 \mathrm{~cm}, 91$ measurements), with upper leve1 electrode set at $7.6 \mathrm{~cm}$.

$4150 \mathrm{I}$

$30 \mathrm{~cm} / \mathrm{s}$ (circuit time $120 \mathrm{~s}$ )

$0.16 \mathrm{~cm} / \mathrm{m}$

Module Specifications

\section{Liftbox}

Construction

Area

Volume at operating depth

Turning box

Construction

Area

Volume at operating depth

Drainbox

Construction

Area

Volume at operating depth

Channel modules

Construction

Area

Volume at operating depth

Recirculation

Construction

Volume

Airlift pumping rate

Airlift life height

Airlift air consumption rate 2-cm plywood painted with fiberglas resin $1.49 \mathrm{~m}^{2}$

$115 \mathrm{~L}$

2-cm plywood painted with fiberglas resin $3.73 \mathrm{~m}^{2}$

$290 \mathrm{~L}$

2-cm plywood painted with epoxy resin

$1.49 \mathrm{~m}^{2}$

$220 \mathrm{~L}$

Spray-molded fiberglas

PVC reinforcements

2 -cm plywood painted with fiberglas resin

$2.98 \mathrm{~m}^{2}$ each module, $41.67 \mathrm{~m}^{2}$ total

$230 \mathrm{~L}$ each module, $3225 \mathrm{~L}$ total

15 cm i.d. PVC pipe

PVC fittings

epoxy resin

silicone glue

(three separate pipes, nested, with separate airlifts)

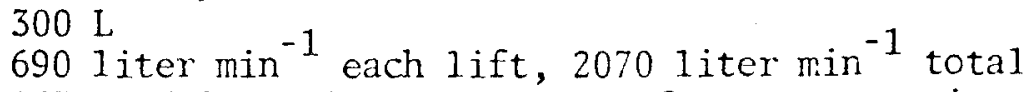

$163 \mathrm{~cm}$ (air outlet to water surface at operating depth) -1 

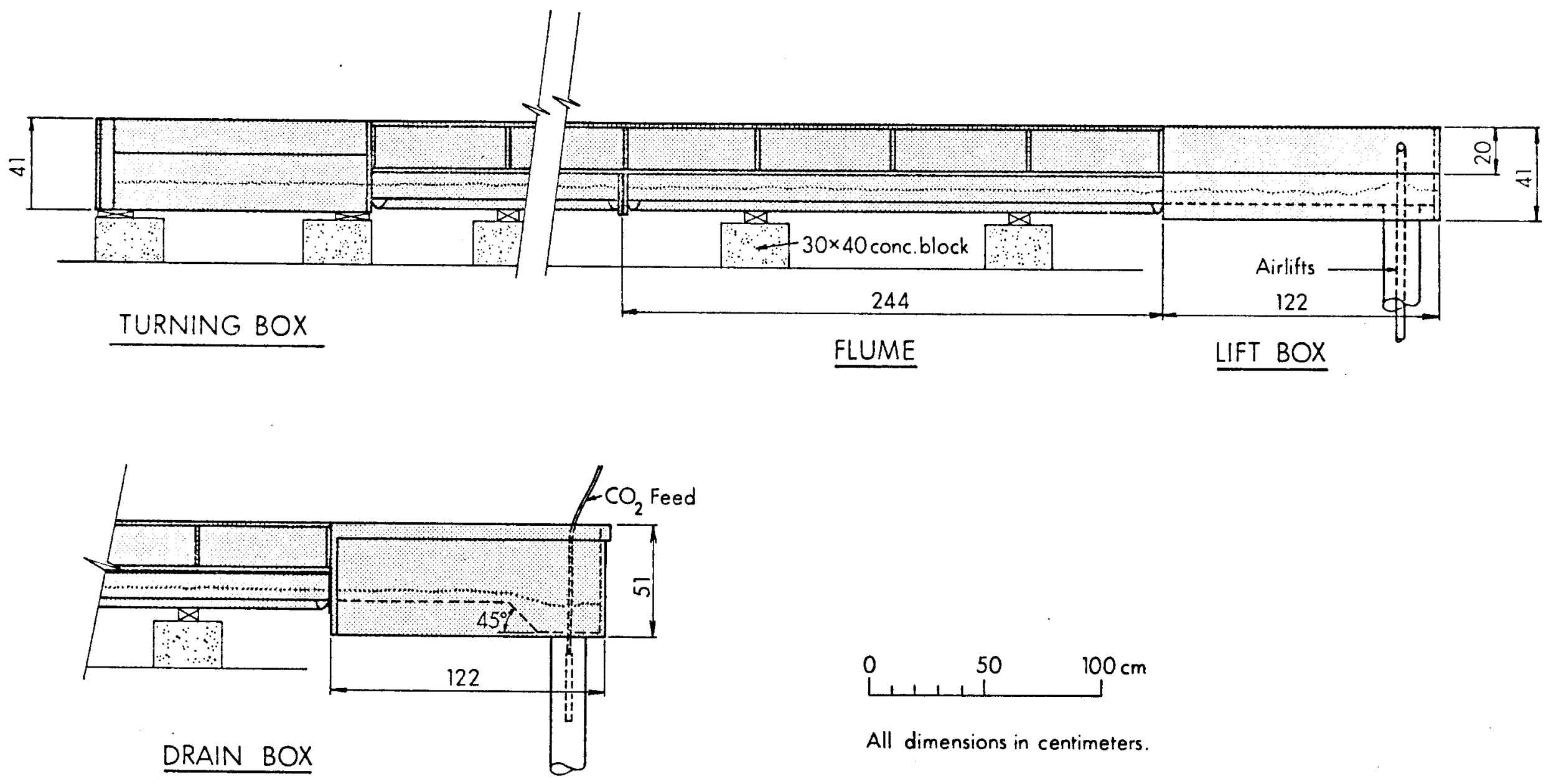

Flgure 2-2. Cross section of flume modules indicating positioning of alrlift and $\mathrm{CO}_{2}$ feed. 


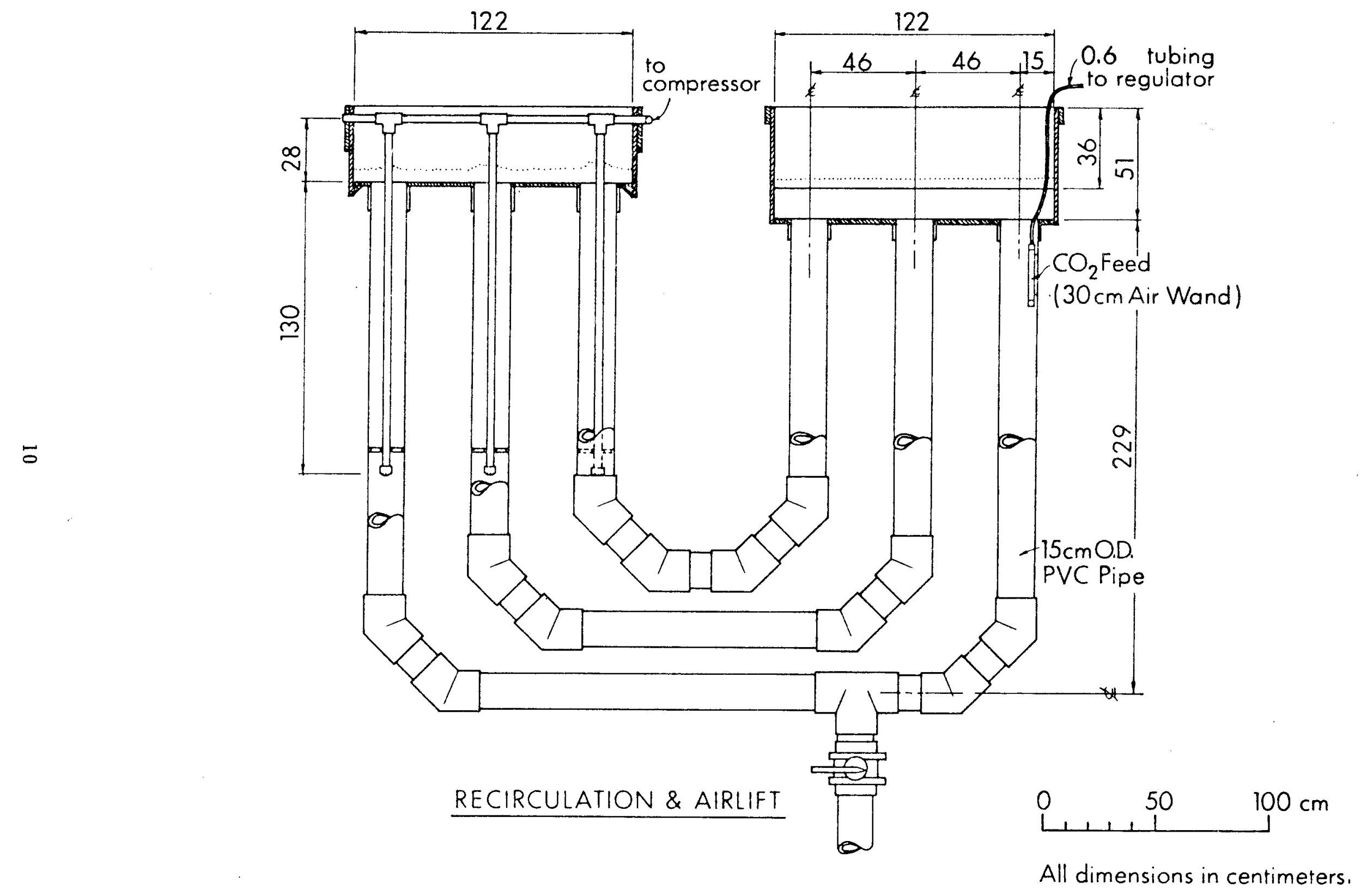

Flgure 2-3. Detail of recirculation and airlift system, 
outside diameter PVC pipe turned in a U-shape using $45^{\circ}$ PVC elbows to reduce flow resistance over that which would be introduced by $90^{\circ}$ elbows. Each of the two inner recirculation pipes has a small arain port at the bottom of the $U_{\text {; }}$ there is a 15-cm valve and drain line located in the outermost recirculation pipe which allows the culture to be transfered to the culture storage tank (Figure 2-4). The airlifts are fed by $2.4 \mathrm{~cm}$ PVC pipes which discharge $1.4 \mathrm{~m}$ below the water surface. Oil-free air is supplied by a Euller Co. 7.5 horsepower model $4 \mathrm{MV}-\mathrm{F}$ air blower. $\mathrm{CO}_{2}$ gas additions are made utilizing an aquarium airstone at a depth of $1 \mathrm{~m}$ in the downward-flowing portion of the recirculation pipes.

A seawater system (Figure 2-4) provides capabilities for adding seawater to the flume, obtaining seawater for laboratory use, partially or completely draining the flume, and storing the culture or seawater. Seawater is drawn from a 45-m-deep well. The seawater is filtered through coral rubble, and is therefore very low in particulate organic matter. Levels of major inorganic nutrients are typically $50 \mu M$ ammonium and $0.8 \mu M$ phosphate. The inlet to the seawater pump is from the saltwater well or from the storage tanks. The outlet is to the flume, to the utility outlet, or to waste. The flume can be drained into the culture storage tank through the $15-\mathrm{cm}$ PVC pipe using a manual valve, and pumped from that tank to any of the outlet ports, or discarded by gravity through the waste port. Wastewater is discharged into an underground sump excavated in the coral rubble.

The flume incorporates a computer-based system that monitors and controls the physical and chemical environment of the culture. The system controller is a Hewlett-Packard model $9845 \mathrm{~B}$ computer, which acquires data from the sensors and manipulates the control devices based on the information received. The seavater pump is controlled on the basis of the operator input and the output of the level detector. Carbon dioxide gas ( $100 \%$ pure) addition is controlled on the basis of $\mathrm{pH}$. Draining is controlled on a timeof-day basis.

Laboratory culture experiments were performed using IMR medium (24) sterile-filtered through $0.22 \mathrm{\mu m}$ Millipore membrane filters. polycarbonte culture tubes $(25 \mathrm{~mm} \times 150 \mathrm{~mm})$ were placed in a temperature controlled $\left( \pm 0.1^{\circ} \mathrm{C}\right)$ water bath in front of a bank of daylight fluorescent bulbs which supplied light at an irradiance of $450 \mu \mathrm{Einst} \mathrm{m}^{-2} \mathrm{~s}^{-1}$. Light was provided on a $12: 12 \mathrm{~L}: \mathrm{D}$ illumination cycle. The biomass of the cultures in each tube was monitored through measurements of in vivo fluorescence on a Turner model 10 fluorometer. Fluorescence measurements were made at the same time each day to avoid artifacts associated with light:dark periodicity.

The four $9.2 \mathrm{~m}^{2}$ flumes are similar in design to the $48 \mathrm{~m}^{2}$ flume, but consist of two channels $7.6 \mathrm{~m}$ long by $0.6 \mathrm{~m}$ wide by $0.15 \mathrm{~m}$ decp. The channels are connected by $20 \mathrm{~cm}$ recirculation pipes; onc (it the two recirculation pipes of each culture contains; an ailiti 


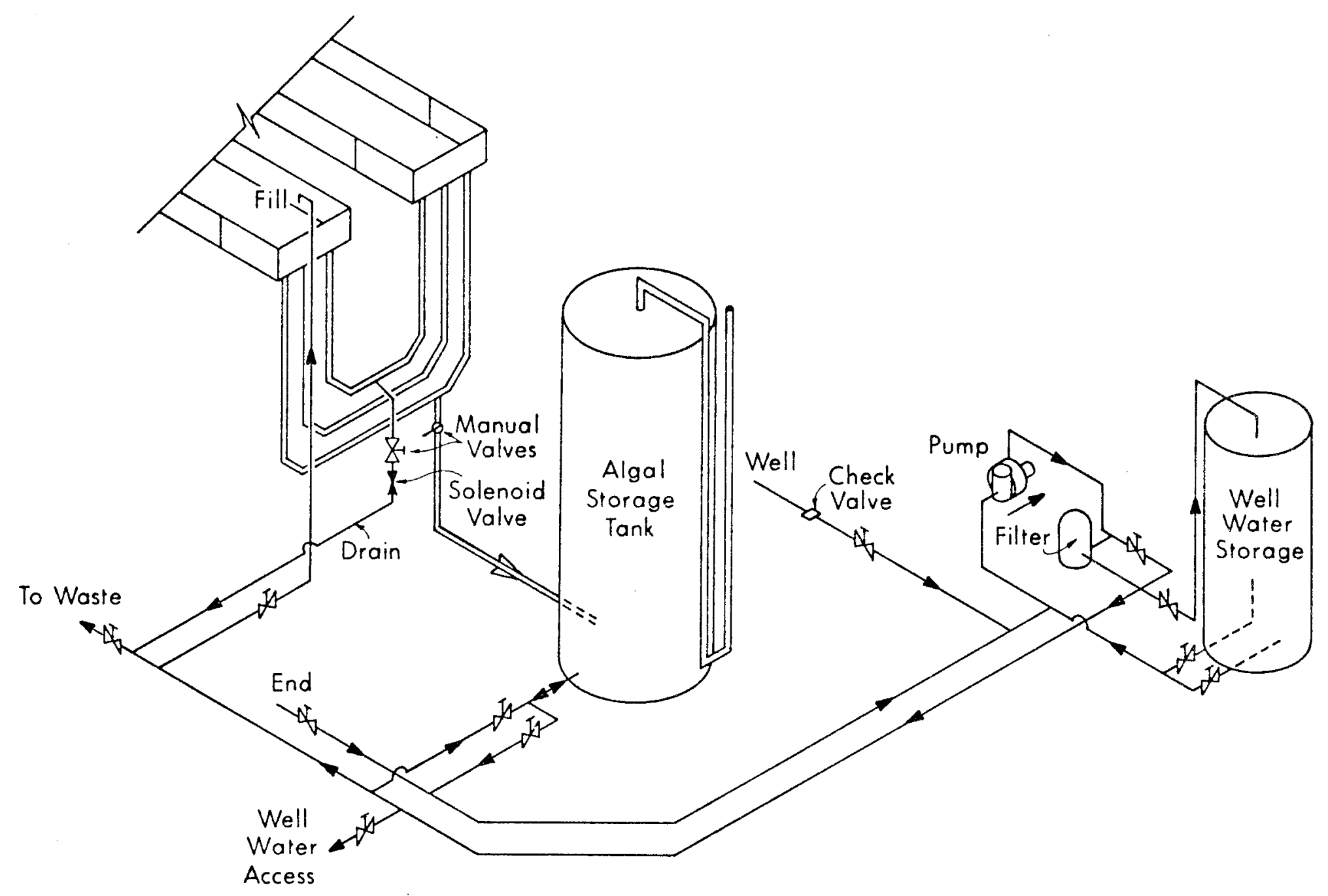

Figure 2-4. Schematic of secwater supply system and algal
storage tank, 
gump which drives culture recirculation. Fach $9.2 \mathrm{~m}^{2}$ flume is equipped with a con supply line. pH sensors in the cultures supply data to the Hewlett-packard $9845 \mathrm{~B}$ computer, which in turn controls the $\mathrm{CO}_{2}$ supply solenoids.

\subsection{ANALYTICAL DATA}

production in the flume was calculated from daily changes in particulate carbon (PC) concentrations corrected for dilution due to arainage and introduction of fresh medium. Samples for PC analyses were collected on glass-fiber (GE/C) filters and analyzed on a Hewlett-Packard model $185 \mathrm{~B}$ CHN analyzer following procedures recommended by Sharp (25). These carbon production numbers were converted to ash-free dry weight production by multip?ying by the experimentally reported ratio of ash-free dry weight:PC. For Platymonas (= Ietraselmis) this ratio is 2.l (26). The proximate composition of the algae was obtained by partitioning the ash-free dry weight (AFDW) between lipid, protein and carbohydrate. The lipid content was estimated using a modified Bligh-Dyer extraction. The protein content was estimated to be 6.25 times the nitrogen content (26). carbohydrate content was estimated by difference, i.e. carbohydrate = AFDW - lipid - protein.

Solar irradiance was measured with a Lambda model I.I-1905B quantum sensor, which has a nearly flat response to light in the wavelength range 400-700 $\mathrm{nm}$ (i.e. photosynthetically active radiation or PAR). Visible quantum fluxes were converted to energy fluxes using the spectral distribution of sunlight (27). The conversion ratio was $19.5 \mu$ Einst per calorie. The caloric content of the microalgae was calculated from the proximate analysis and energy contents of $9.3 \mathrm{kcal}^{-1}$ for $1 \mathrm{ipid}, 4.2 \mathrm{kcal}$ $\mathrm{g}^{-1}$ for carbohydrate, and $5.7 \mathrm{kcal}^{-1}$ for protein (28). Solar energy conversion efficiencies were calculated based on this caloric content and the incident energy flux of visible light.

SECTION 3.0

RESULTS

\subsection{TASK I: SCREENING OF CANDIDATE SPECIES IN LABORATORY CULTURES}

Objective: o To determine which microalgal species are most likely to grow well at elevated temperatures in culture systems, and to select three or more for outdoor yield studies

Purpose $\quad$ To reduce the number of species which must be studied in the outdoor flume factorial experiments 
Most marine phytoplankton do not grow well at temperatures in excess of $30^{\circ} \mathrm{C}$. For example, of seven tropical diatom isolates from surinam, three exhibited no growth at $33^{\circ} \mathrm{C}$, and the remaining four exhibited no growth at $37^{\circ} \mathrm{C}(29)$. However, some species exhibit remarkable thermal tolerance. A strain of chaetoceros gracilis has been reported to grow optimally in the temperature range $23-37^{\circ} \mathrm{C}$, and to be capable of growth in the temperature range $11-41^{\circ} \mathrm{C}(30)$. Since the temperature in our Elumes typically reaches $34-35^{\circ} \mathrm{C}$ for an hour or two during each day in the summer, we felt that the ability of the cultured organism to grow at temperatures approaching $35^{\circ} \mathrm{C}$ would be necessary if the flumes were to be operated without temperature controls.

Table 3-1 and Figure 3-1 show the results from our laboratory studies for those species which we found capable of growth at $32^{\circ} \mathrm{C}$ and $34^{\circ} \mathrm{C}$. None of these species exhibited any growth at $36^{\circ} \mathrm{C}$. The best overall growth at 32 and $34^{\circ} \mathrm{C}$ was displayed by Platymonas sp., a species which initially appeared as a contaminant in our outdoor flumes during studies of P. tricornutum. Our experience with this species both in the laboratory and in the outdoor culture system indicates that it grows well over the temperature range $20-34^{\circ} \mathrm{C}$, and is therefore a promising candidate for year-round culture in Hawaii or in the southwestern U.S. A culture of platymonas sp. was sent to Dr. William Barclay at SERI for inclusion in the SERI culture

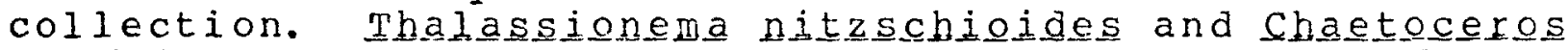
gracilis closely followed Platymonas with respect to growth rate at 32 and $34^{\circ} \mathrm{C}$. The culture of the former species was subsequently lost as a result of an electrical problem with our incubator. However, both c. gracilis and Isochrysis survived, and were subsequently tested for production potential in the experimental outdoor flumes. It is noteworthy that $c$. gracilis did not grow at $36^{\circ} \mathrm{C}$, although the strain is reportedly identical to the strain which was earlier reported to grow at $11-41^{\circ} \mathrm{C}(30)$. Our results indicate that this strain may have lost some of its thermal tolerance after almost 20 years in culture collections.

\subsection{TASK II: YIELD OPTIMIZATION OF PROMISING SPECIES IN SHALLOW OUTDOOR FLUMES}

Objectives: o To determine how much algal production can be expected from shallow outdoor flumes without temperature control

- To determine the sensitivity of the production function to changes in design characteristics

Purpose o To determine whether the production of shallow outdoor flumes can be maintained or even enhanced by foregoing temperature control and by growing thermophilic microalgae during the warm summer months 
Table 3-1. Log phase growth rates (doublings per day) of four strains of microalgae which grew at temperatures of $32^{\circ} \mathrm{C}$ and $34^{\circ} \mathrm{C}$.

Temperature

Source $\quad 32^{\circ} \mathrm{C} \quad 34^{\circ} \mathrm{C}$

Chaetoceros gracilis

Univ. British Columbia $0.66 \quad 0.69$ culture collection

Isochrysis (Tahitian)

R. York, Hawaii Inst. 0.450 .71 Mar. Biol. culture collection

P1atymonas sp.

isolated from our mass $0.65 \quad 0.82$ culture flume

Thalassionema nitzschioides Kaneohe Bay, Hawaii $\quad 0.56 \quad 0.83$ 

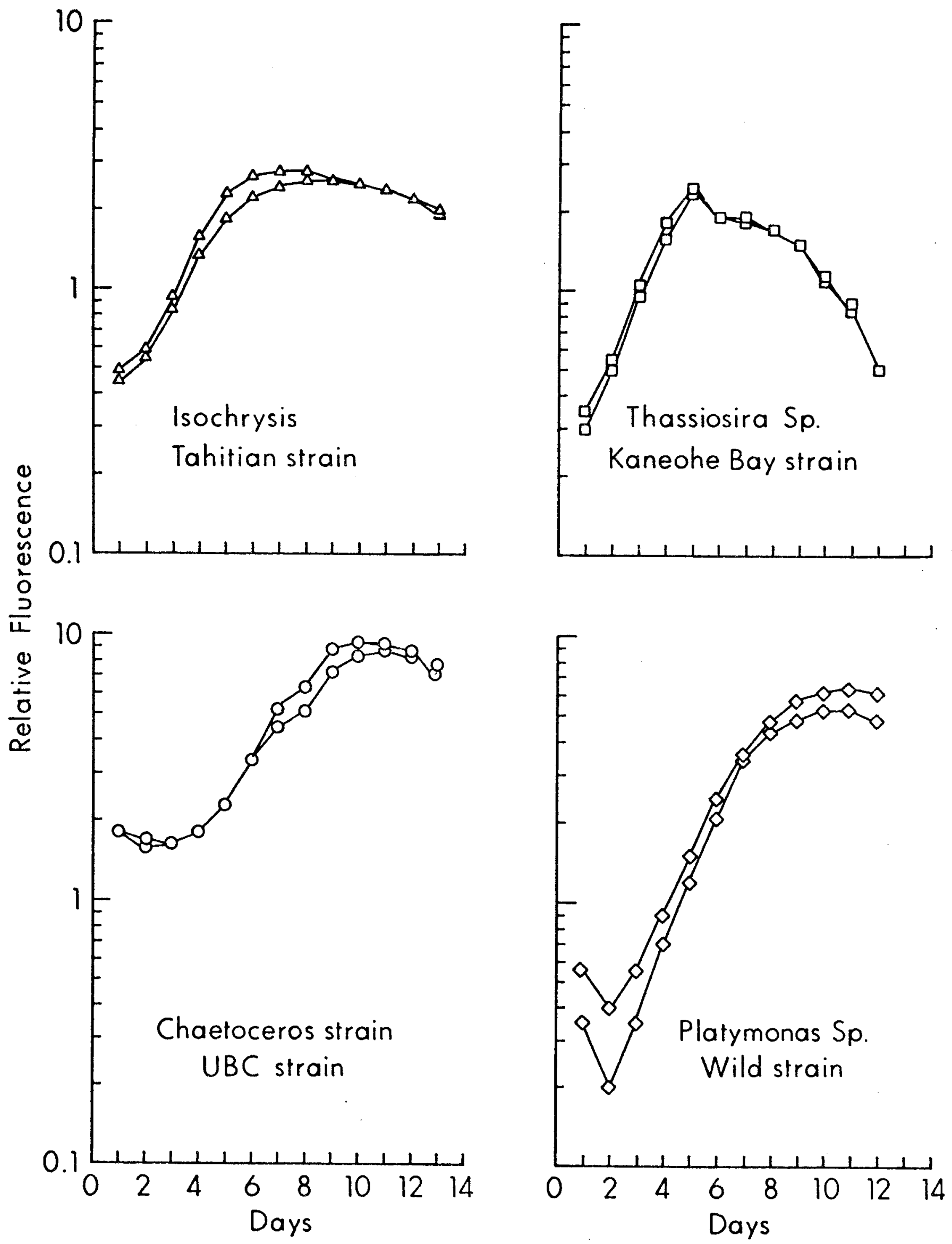

Figure 3-1. Growth of four species of marine microalgae at $34^{\circ} \mathrm{C}$ in IMR medium 


\subsection{FRACTIONAL FACTORIAL EXPERIMENTS WITH PLATYMONAS}

The species most thoroughly studied in the outdoor flumes was Platymonas. During our earlier work with P. tricornutum (31) we performed a first-order factorial experiment in which the following parameters were each assigned two values:

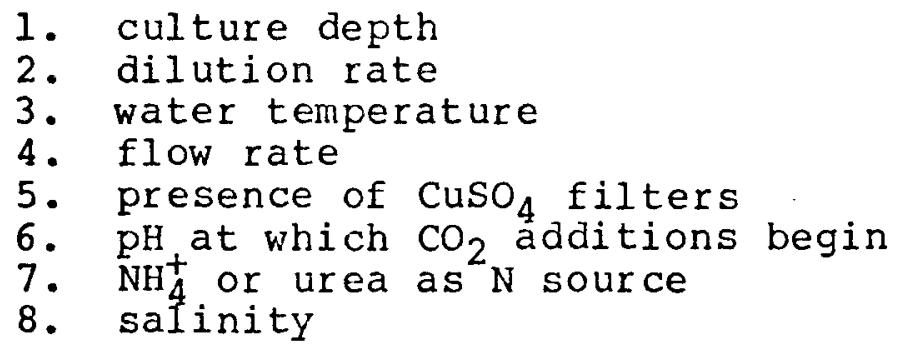

In the present studies no effort was made to control water temperature, and $\mathrm{CuSO}_{4}$ filters were not used. The decision to eliminate the $\mathrm{CuSO}_{4}$ ilters was based on the fact that the filters themselves remove $50 \%$ of incoming visible light, and although our work with p. tricornutum indicated that. photosynthesis was more efficient in blue light, the increase in efficiency was consistently less than the factor of two necessary to make up for the loss of $50 \%$ of the visible light. First order factorial experiments with Platymonas indicated that

1. production was as good at $15 \%$ as at $35 \%$ salinity

2. $\mathrm{NH}_{4}^{+}$and urea were equally good sources of $\mathrm{N}$ (not a surprising result, since $\left.\mathrm{CO}\left(\mathrm{NH}_{2}\right)_{2}+\mathrm{H}_{2} \mathrm{O} \rightarrow 2 \mathrm{NH}_{3}+\mathrm{CO}_{2}\right)$

3. production is higher at a flow rate of $30 \mathrm{~cm} / \mathrm{s}$ than at $15 \mathrm{~cm} / \mathrm{s}$

4. production is insensitive to culture depth between 8 and $12 \mathrm{~cm}$, but is reduced at shallower and deeper depths

5. production is a sensitive function of dilution rate and the $\mathrm{pH}$ at which $\mathrm{CO}_{2}$ addition begins

Since a flow rate of $30 \mathrm{~cm} / \mathrm{s}$ was close to the maximum we could achieve with our airlift system, we chose to conduct subseguent experiments at that flow rate. Salinity was set at $35 \%$, culture depth at $10 \mathrm{~cm}$, and $\mathrm{NH}_{4}^{+}$was chosen as the $\mathrm{N}$ source. A second-order factorial design experiment in which dilution rate and $\mathrm{pH}$ were varied was then used to determine the optimum production conditions. The results are shown in Figure $3-2$. Each data point represents mean results obtained over at least a one-week period. Note that dilution rates in this figure refer to once-a-day dilutions, not to continuous dilution rates. For example, our 50 o dilution rate (requiring a doubling per day to maintain steady state cell numbers) would correspond to a continuous dilution rate of $69.3 \%$ per day.

In order to describe the experimental results, an analytical function of the form

$$
\begin{gathered}
Y=C_{o}+c_{1} \mu+c_{2} p H+c_{3}{ }^{2}+c_{4} p^{2} \\
c_{5} \mu p H+c_{6} \mu^{4}
\end{gathered}
$$




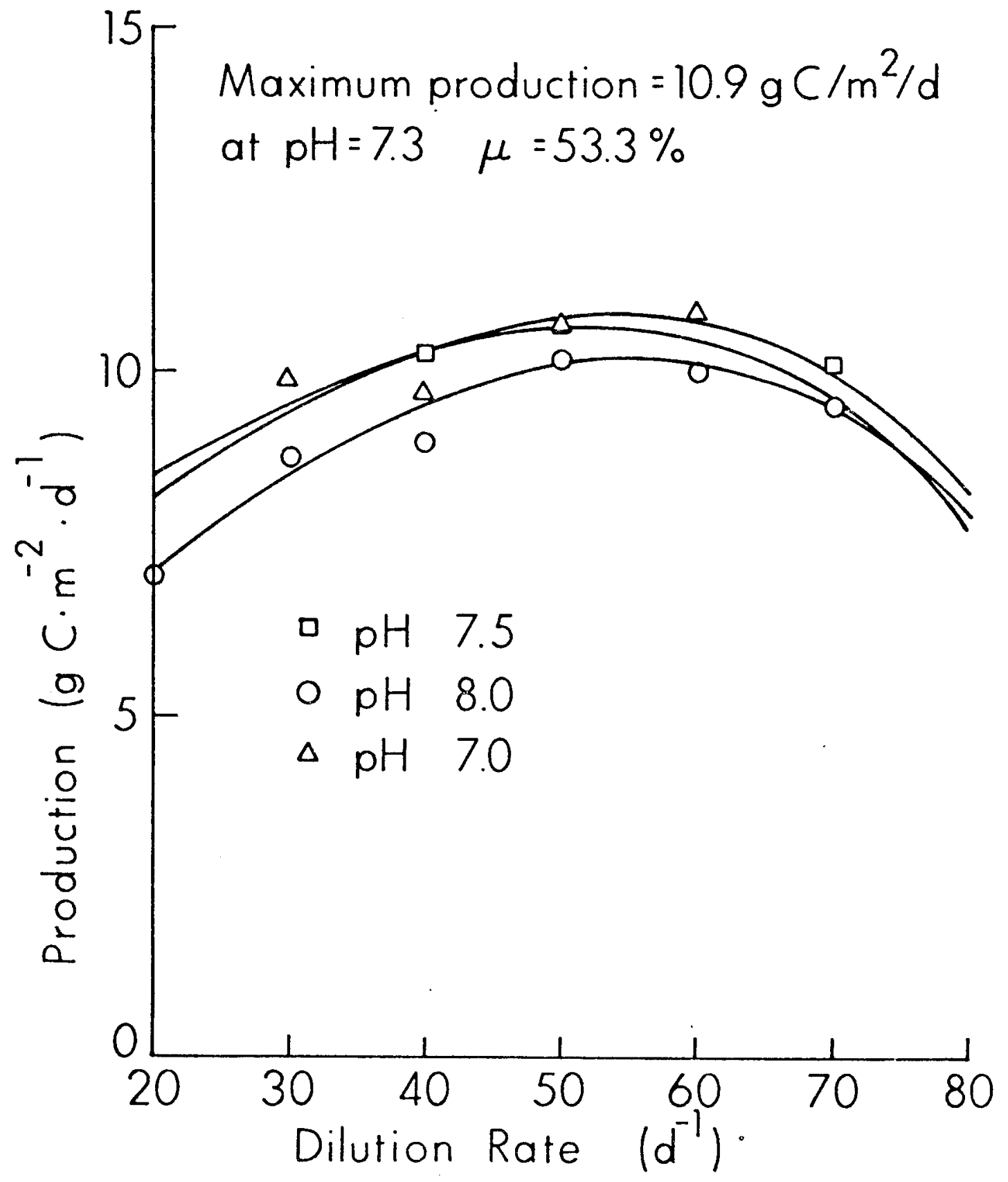

Figure 3-2. Platymonas production as a function of $\mathrm{pH}$ and dilution rate. Curved lines are fit of Eq. 1 to data 
was fit by least squares to the data. In Equation 1 y is the response function (pioduction or photosynthetic efficiency), is the dilution rate, and $\mathrm{pH}$ is the $\mathrm{pH}$ at which $\mathrm{CO}_{2}$ additions began. The optinum production obtained from the fit to the data in Figure $3-2$ was $10.9 \mathrm{gC} \mathrm{m}^{-2} \mathrm{a}^{-1}$ at a $\mathrm{pH}$ of 7.3 and a dilution rate of 53\%. The corresponding photosynthetic efficiency based on PAR was 7\%. Since $\mathrm{pH}=7.0$ corresponds to having the $\mathrm{CO}_{2}$ bubbling essentially all the time during the photoperiod, there was no reason to explore lower pH's. Furthermore, setting the pH at 7.0 results in a very low efficiency of $\mathrm{CO}_{2}$ utilization ( 258 ; see later discussion). Since production is rather insensitive to pH in the pH range $7.0-7.5$, we elected to conduct further experiments in the large flume at a pH of 7.5 .

Two experiments were run to check on the reproducability of results, and the results are shown in Table 3-2. The results indicate that the standard deviations are 5-10\% of the means. As a further check we repeated certain conditions in individual flumes on different weeks, and obtained very similar results. For example at $\mathrm{pH}=7$ and $\mu=40 \%$, production on two successive weeks was 10.29 and $10.64 \mathrm{gC} \mathrm{m}^{-2} \mathrm{~d}^{-1}$, and at $\mathrm{pH}=7.5$ and $\mu=50 \%$, production on two successive weeks was 11.32 and $11.68 \mathrm{gC} \mathrm{m}^{-2} \mathrm{~d}^{-1}$. Thus results were reasonably reproducible from week to week and from flume to flume.

The principal accomplishment of this phase of the reseach was to show that good production could be achieved in a shallow outdoor flume system without temperature control. In fact, the results obtained from the factorial studies with platymonas were slightly better than those obtained using a temperature-controlled system with P. tricornutum (31). Removal of the temperature control constraint was a big step towards making the culture operation energetically favorable.

Tables 3-3 and 3-4 contain the results of some exploratory experiments we performed in the small flumes with platymonas before setting up a long-term production run in the large flume. The results in Table 3-3 were obtained at a dilution rate of 50\% per day and a pH of 7.5. However, in two cases we controlled pH by bubbling $\mathrm{CO}_{2}$, and in the other two cases by adding $\mathrm{HCl}$. production was obviously much better when $\mathrm{CO}_{2}$ was used to control pH. The conclusion from this experiment is that $\mathrm{CO}_{2}$ additions are necessary to obtain high production rates, and that the influx of $\mathrm{CO}_{2}$ from the atmosphere is not adequate to keep up with the demands of the algae, even if the $\mathrm{pH}$ is maintained at 7.5 with acid so as to prevent the conversion of dissolved $\mathrm{CO}_{2}$ to bicarbonate at higher pH's. The data in Table 3-4 were in tact obtained as part of our first-order factorial studies, and indicate that production is not significantly affected by salinity in the range $15-30 \%$ oo or by culture depth between 8 and $12 \mathrm{~cm}$. In all cases the dilution rate was $50 \mathrm{~s}$ per day and the flow rate $30 \mathrm{~cm} / \mathrm{s}$. 
Table 3-2. Production results in $9.2 \mathrm{~m}^{2}$ flumes operated under identical conditions. Culture depth was $10 \mathrm{~cm}$ and dilution rate $50 \%$ per day in all cases. Production values are daily means ( $\mathrm{g} \mathrm{C} \mathrm{m}^{-2}$ ) over a one-week period.

$\begin{array}{ccc}\text { flume } & \mathrm{pH}=8 & \mathrm{pH}=7.5 \\ 1 & 11.2 & 11.3 \\ 2 & 9.1 & 11.4 \\ 3 & 10.8 & 12.5 \\ 4 & 9.6 & 11.5 \\ \text { mean } \pm \text { SD } & 10.2 \pm 1.0 & 11.7 \pm 0.6\end{array}$


Table 3-3. Production results in $9.2 \mathrm{~m}^{2}$ flumes run at a depth of $10 \mathrm{~cm}$ and dilution rate of $50 \%$ per day. $\mathrm{pH}$ was controlled at 7.5 either by $\mathrm{CO}_{2}$ bubbling or addition of $\mathrm{HCl}$. Results are average daily production rates $\left(\mathrm{gC}^{-2}\right)$ over the indicated number of days.

$\begin{array}{cccc}\text { flume } & \mathrm{pH} \text { control } & \text { Production } & \begin{array}{c}\text { duration of run } \\ \text { (days) }\end{array} \\ 1 & \mathrm{HC} 1 & 8.6 \pm 3.2 & 6 \\ 2 & \mathrm{HC} 1 & 9.2 \pm 4.5 & 6 \\ 3 & \mathrm{CO}_{2} & 13.2 \pm 3.5 & 4\end{array}$


Table 3-4. First-order factorial production results in $9.2 \mathrm{~m}^{2}$ flumes with platymonas. Culture depth was $10 \mathrm{~cm}$, dilution rate $50 \%$ per day. Results are daily production rates $\left(\mathrm{gC} \mathrm{m}^{-2}\right)$ averaged over a two-week period.

$$
\text { Salinity }(\%)
$$

15

culture depth

$(\mathrm{cm})$

8

12
$9.0 \pm 3.1$

$9.3 \pm 2.1$
$9.4 \pm 1.9$

$10.6 \pm 3.5$ 


\subsection{NUTRIENT STARVATION STUDIES WITH PLATYMONAS}

Figures $3-3$ and $3-4$ illustrate the results of a nutrient starvation study with Platymonas performed in the small flumes during November, 1983. At the start of the experiment all four flumes were in the same condition, and had been operated in a nutrient-saturated mode at a dilution rate of $50 \%$ per day and $\mathrm{pH}$ $=7.5$ for a period of one week. Beginning on day one $P$ additions were terminated to one flume, N additions were terminated to a second flume, and both $N$ and $P$ additions were terminated to a third flume. One flume continued to be operated in a nutrient saturated mode. As can be seen in Figure 3-3, the $\mathrm{C} / \mathrm{N}$ ratios in the nutrient-saturated and $\mathrm{P}-1$ imited flumes showed no significant temporal variation over the subsequent two-week period, and there was no significant temporal trend in the lipid content of these flumes over a time period of almost three weeks (Figure 3-4). Thus $\mathrm{P}$ limitation had no significant impact on the lipid content or gross composition of the cells. However, the $\mathrm{C} / \mathrm{N}$ ratio in the N-limited cells increased from about 6.5 to 8 by weight during the second week of starvation (Figure 3-3), and the $\mathrm{C} / \mathrm{N}$ ratio of the $N$ and $P$ limited cells steadily incrased from about 6.5 to over 12 by weight between days 4 and 14 of the starvation. Thus there was evidence that both N Iimitation and $N+P$ Iimitation triggered an increase in the percentage of carbon storage products in the cells, with $\mathrm{N}+$ Plimitation producing the most rapid and much greater accumulation of storage products. Figure 3-4 however shows that the percentage of lipids in the $\mathrm{N}$ limited and $\mathrm{N}+\mathrm{P}$ limited cells actually declined steadily from day 5 to day 19 of the starvation. The measured $\mathrm{C} / \mathrm{N}$ ratios and lipid composition values combined with the fact that the ratio of AFDW to carbon in Platymonas is 2.1 can be used to perform a crude compositional analysis of these cells, and the results are shown in Table 3-5. It is clear from the results in this table that the increased $\mathrm{C} / \mathrm{N}$ ratios observed in the $\mathrm{N}-\mathrm{Iimited}$ and $\mathrm{N}+\mathrm{P}$ limited cultures reflect carbohydrate storage rather than lipid storage, and that the increased carbohydrate content is balanced largely by a reduction in the protein content. We conclude from these studies that platymonas can be induced to produce storage products by means of nutrient starvation, that simultaneous $N+P$ limitation is the most effective way to induce the production of these storage products, that the storage products will be carbohydrates, and that the increase in the carbohydrate content of the cells will be balanced largely by a reduction in their protein content.

\subsection{LONG TERM PRODUCTION RUN WITH PLATYMONAS}

On $1 / 1 / 84$ we began a five-month continuous run with Platymonas in the $48 \mathrm{~m}^{2}$ flume. The results of this run in terms of AFDW production and photosynthetic efficiency based on PAR are shown in Figure 3-5. Table 3.6 lists monthly means for solar radiation (PAR) and maximum and minimum water temperatures during the study period. Daily data have been tabulated in the appendix. The purpose of this experiment was to operate the large flume in the 


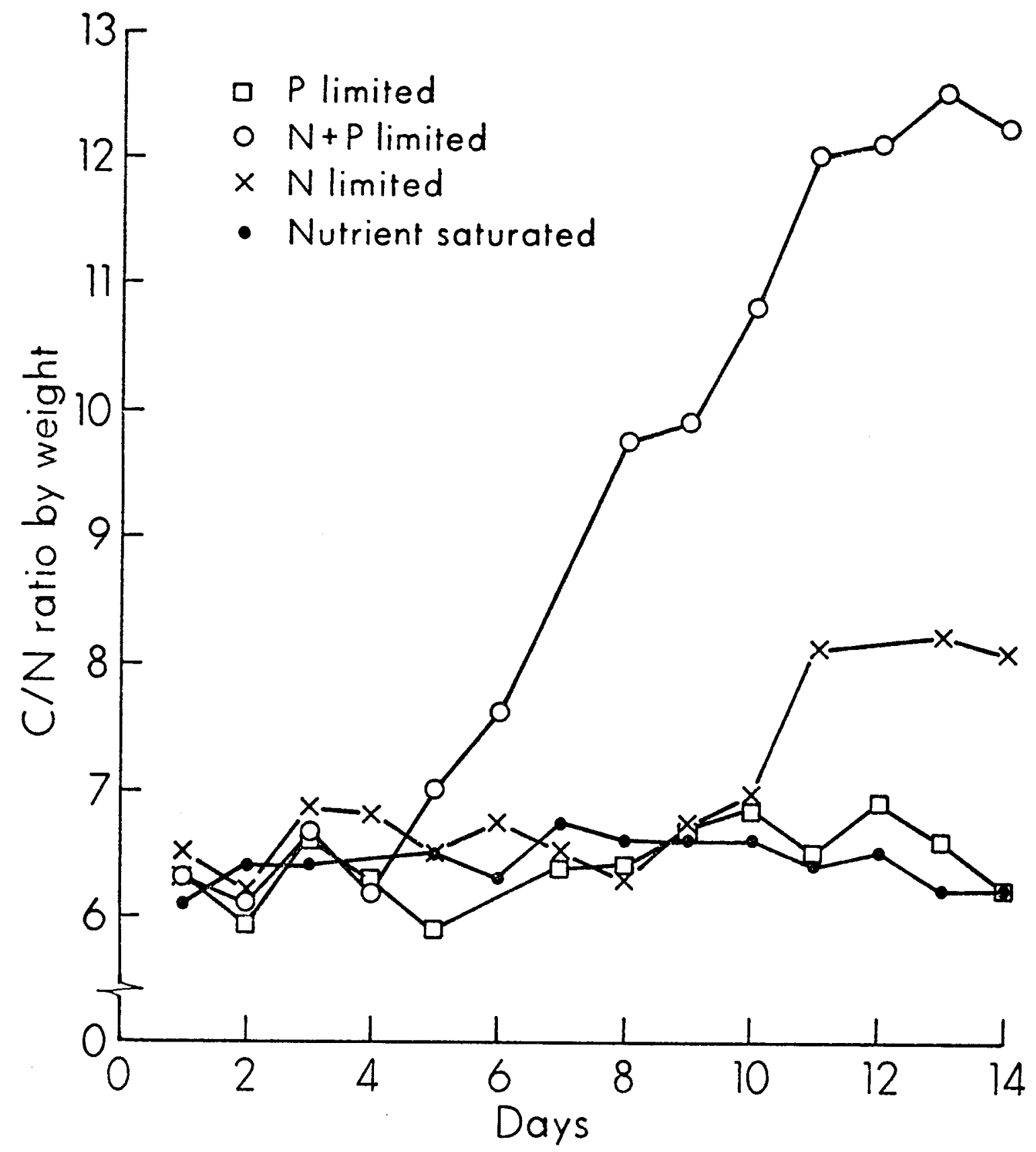

Figure 3-3. C/N ratios during period of nutrient starvation in Platymonas culture. 


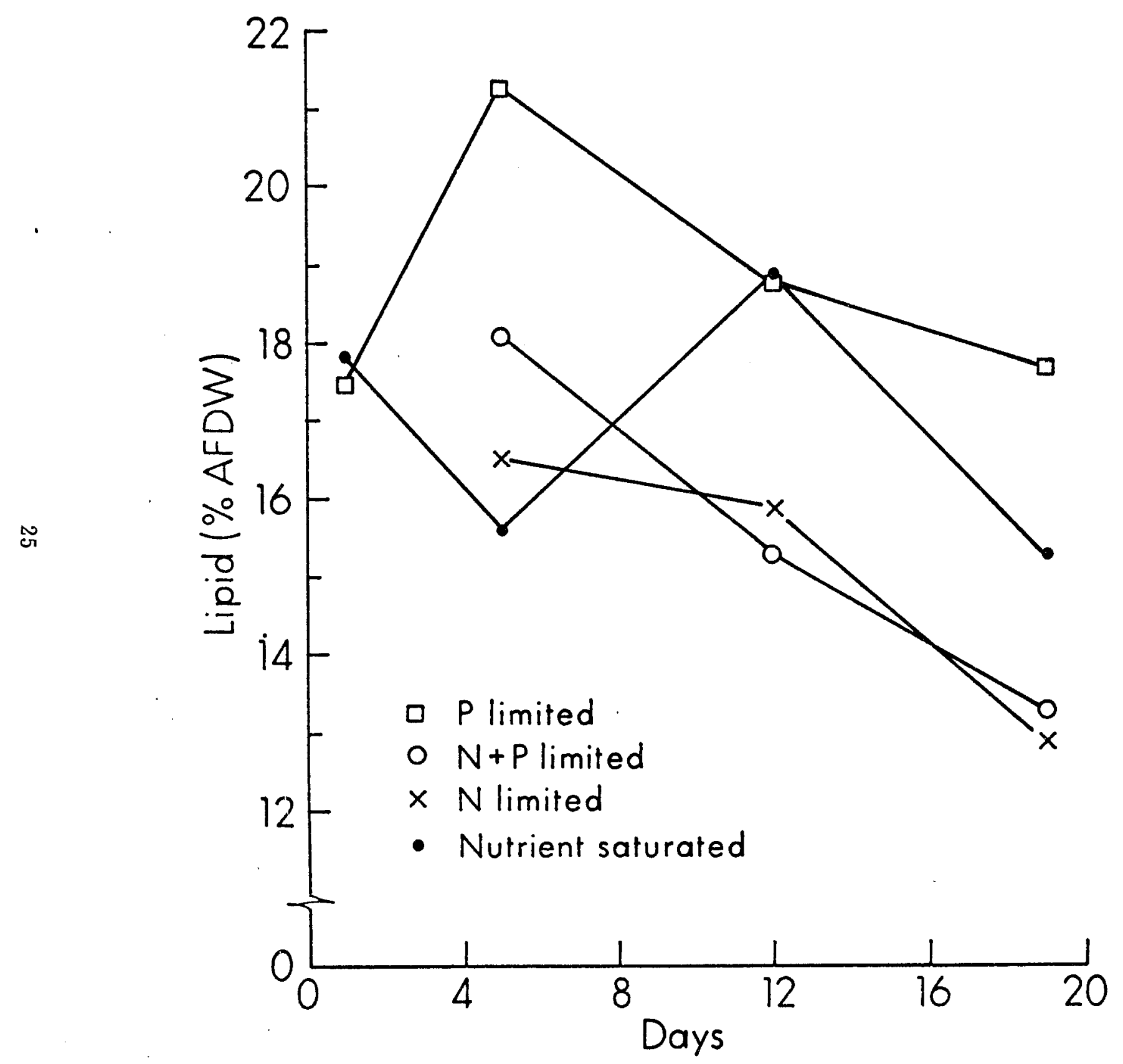

Figure 3-4. Lipid content of Platymonas cul tures during nitriant stan/ntinn sting. 
Table 3-5. Compositional analysis of platymonas cells at start of nutrient starvation experiment (in parentheses) and after 14 days of starvation.

\begin{tabular}{|c|c|c|}
\hline protein & 1 ipid & carbohydrate \\
\hline$(47)$ & $(18)$ & $(35)$ \\
\hline 46 & 18 & 36 \\
\hline 46 & 18 & 36 \\
\hline 36 & 15 & 49 \\
\hline 24 & 15 & 61 \\
\hline
\end{tabular}

$\begin{array}{lccc}\text { nutrient-saturated } & 46 & 18 & 36 \\ \text { P-1imited } & 46 & 18 & 36 \\ \text { N-1imited } & 36 & 15 & 49 \\ \text { N }+ \text { P-1imited } & 24 & 15 & 61\end{array}$




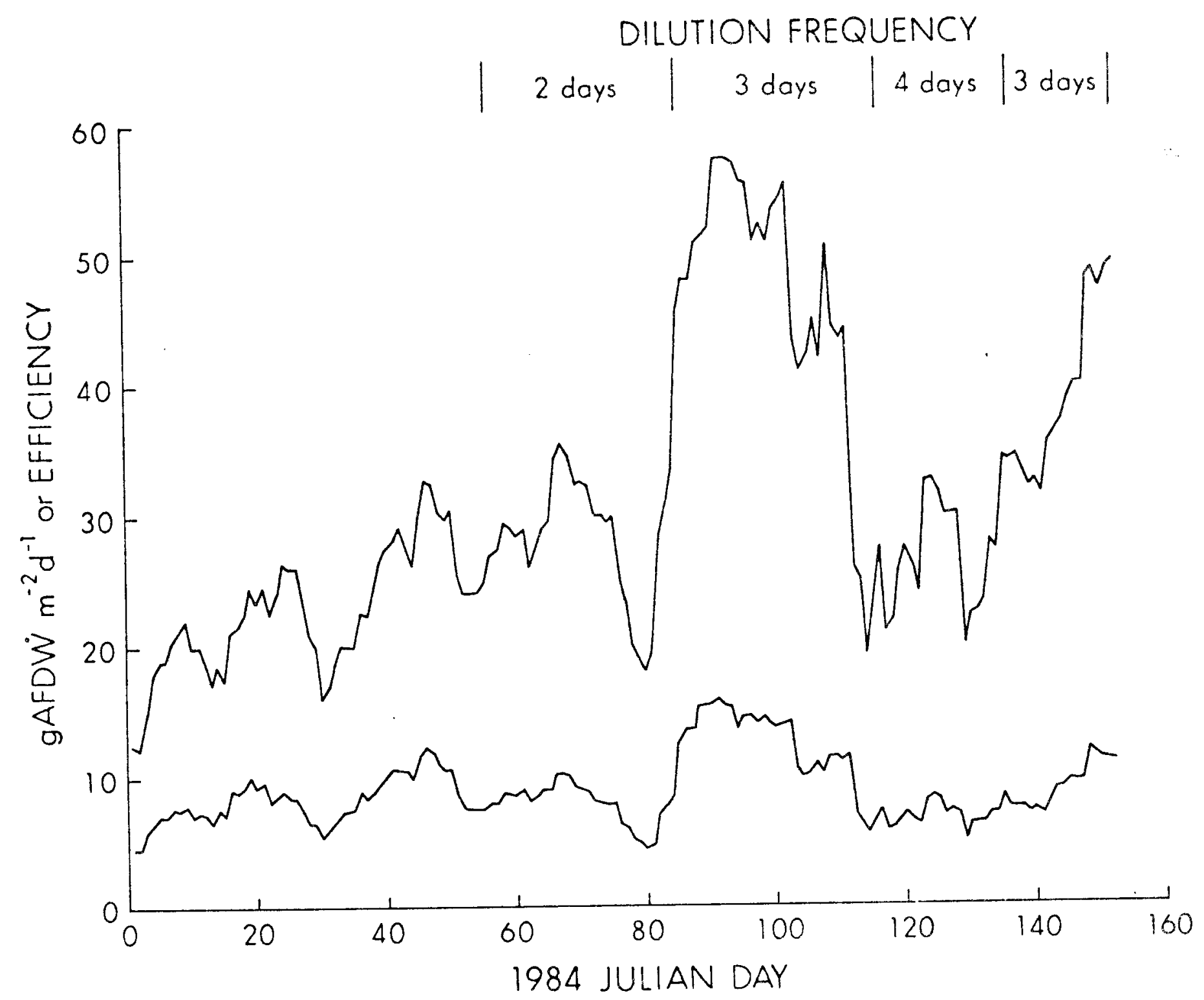

Figure 3-5. Long term Platymonas production and photosynthetic efficiency resul ts in $4 \mathrm{~m}^{2}$ flume. Data points are six-day running means 
Table 3-6. Monthly means of solar radiation (PAR) and maximum and minimum water temperatures in $48 \mathrm{~m}^{2}$ flume during January - May, 1984 .

\begin{tabular}{lccc} 
Month & $\begin{array}{c}\text { Solar Radiation } \\
\left.\text { (PAR, Einst } \mathrm{m}^{-2} \mathrm{~d}^{-1}\right)\end{array}$ & \multicolumn{2}{c}{ Water Temperature $\left({ }^{\circ} \mathrm{C}\right)$} \\
Nanuary & 35.3 & Ninimum & Maximum \\
Jebruary & 36.7 & $21.6 \pm 1.1$ & $30.6 \pm 2.0$ \\
March & 45.7 & $20.9 \pm 1.4$ & $30.2 \pm 1.4$ \\
Apri1 & 49.5 & $21.4 \pm 1.1$ & $32.2 \pm 1.1$ \\
May & 54.0 & $21.7 \pm 0.8$ & $31.8 \pm 1.7$ \\
& & $22.4 \pm 0.7$ & $32.8 \pm 1.7$
\end{tabular}


mode which the earlier factorial experiments had indicated should be optimal, and to determine what sort of long term production results could be obtained. During the early portion of this run such a policy was followed, but other events and discoveries led to modifications in our operating procedures which ultimately proved highly beneficial. During the first few months of the study we attempted to operate both the $48 \mathrm{~m}^{2}$ flume and the four small flumes. Two problems became apparent during this time. First, the amount of air generated by our 3.5 horsepower air compressor was inadequate to produce proper flow rates in all the flumes. This problem was corrected by installation of a 7.5 horsepower air blower in mid-February. The second problem concerned the quality of the water we obtained from our saltwater well. This water is anoxic when it comes out of the ground, and pretreatment by means of air bubbling is necessary before the water can be used in the flumes. Unfortunately our well water storage tank (Figure 2-4) was not large enough to treat the water needed to run all five flumes for a sufficient period of time (two days or more). Thus some compromises had to be struck in the dilution schedules until changes could be made in our plumbing system. The changes in the system consisted of installing valves which allowed the well water to be pumped into the algal storage tank (Figure 2-4), which has a much larger capacity than the well water storage tank. With this modification it was possible to give the well water adequate pretreatment before using it in the flumes.

The result of this latter problem is that the large flume was diluted on a somewhat irregular basis until 2/27/84. In some cases the flume was diluted every day for several days; in other cases periods of several days went by when the flume was diluted every other day. Daily production during this time averaged 22.8 g AFDW $\mathrm{m}^{-2}$, and the average photosynthetic efficiency was $7.4 \%$. The irregular dilution pattern turned out to be a blessing in disguise. By scrutinizing the data, we discovered that production tended to be higher on the second day after dilution than on the first day. We therefore hypothesized that diluting the culture every other day might result in higher yields than once daily dilutions. We tested this hypothesis by diluting the large flume every two days for a period of 28 days from $2 / 27 / 84$ to $3 / 25 / 84$. During the first 14 days the culture concentration was reduced to $2 \times 10^{6}$ cells $\mathrm{ml}^{-1}$ after dilution, and during the second two weeks the culture concentration after dilution was $3 \times 10^{6}$ cells mi-1. production was slightly better when the concentration was reduced to $3 \times 10^{6}$ cells $\mathrm{ml}^{-1}$, but the principal result of the study was that production was consistently higher on the second day after dilution. In other words, growth following each dilution was not a linear function of time, but instead gave evidence of being exponential. The average production on the first day after dilution was $23.3 \mathrm{~g}^{\mathrm{AFDW}} \mathrm{m}^{-2}$, and the average daily production on the second day after dilution was $35.6 \mathrm{~g}$ AFDW $\mathrm{m}^{-2}$. Overall daily production during this onemonth time period averaged $29.6 \mathrm{~g}$ AFDW $\mathrm{m}^{-2}$.

Given these results, we hypothesized that diluting the culture 
every three days might result in even higher production. We therefore set up a 30-day run from $3 / 26 / 84$ to $4 / 26 / 84$ during which time the culture was diluted every three days. The cell concentration after dilution was $2 \times 10^{6}$ cells $\mathrm{ml}^{-1}$. A heavy rain on 4/20/84 effectively diluted the culture on two successive days (4/19 and 4/20), and rainy and cloudy conditions during the last week of the study period resulted in relatively low production. However, the average daily production over the 30-day run was $45.9 \mathrm{~g} \mathrm{AFDW} \mathrm{m}^{-2}$. The most remarkable aspect of the results was the consistently high daily production achieved on the third day after dilution, almost $78 \mathrm{~g}$ AFDW $\mathrm{m}^{-2}$. However, daily productions on the first and second days following dilution were not significantly different, and averaged $33 \pm 10$ and $27 \pm 9 \mathrm{~g}$ AFDW $\mathrm{m}^{-2}$. The average photosynthetic efficiency over the 30 -day $r$ un was $11.0 \%$.

Because of the excellent production results achieved with the three-day dilution cycle, we hypothesized that a four-day dilution cycle might be even better, and tested this hypothesis by conducting a 20-day experiment from $4 / 26 / 84$ to $5 / 16 / 84$ in which the $48 \mathrm{~m}^{2}$ flume was diluted every four days. However, daily production during this time averaged only $27.2 \mathrm{~g} \mathrm{AFDW} \mathrm{m}^{-2}$. Daily production on the four days after dilution averaged $26,36,33$ and $14 \mathrm{~g}$ AFDW $\mathrm{m}^{-2}$. There was obviously no day on which production was consistently high, and production on the fourth day was much below that on the other three days. We concluded that a four-day dilution cycle was clearly inferior to a threeday dilution cycle.

From $5 / 16 / 84$ to $6 / 2 / 84$ we diluted the $48 \mathrm{~m}^{2}$ flume every third day in order to check the reproducability of the previousiy observed production pattern, and to perform some additional analyses to try to understand why production was so high when the cells were grown in this mode. The daily production during this time period averaged $40.0 \mathrm{~g} A F D W \mathrm{~m}^{-2}$, and daily production on the three days following each dilution averaged $34.3,21.7$, and $64.0 \mathrm{~g} \mathrm{AFDW}^{-2}$, respectively. The three-day production pattern was thus qualitatively similar to the pattern observed from $3 / 26$ to $4 / 26$ in that production on the third day was 2-3 times greater than the average production on the first two days, and production on the second day was lower than on the first day.

Photosynthetic efficiencies averaged $11.0 \%$ and 8.38 during the 3day dilution cycle runs from $3 / 26$ to $4 / 26$ and from $5 / 16$ to $6 / 2$, respectively. However, photosynthetic efficiencies on the third day after dilution averaged $18.8 \%$ from $3 / 26$ to $4 / 26$. Since the maximum possible photosynthetic efficiency is believed to be about 208 (32), we hypothesized that some of the particulate carbon production observed on the third day after dilution might represent nonphotosynthetic production. We postulated that the cells might have been releasing dissolved organic carbon (DOC) into the water during the first two days after dilution, and then reassimilating the excreted DoC on the third day. To test thig hypothesis we measured Doc concentrations in one of the $9.2 \mathrm{~m}^{2}$ flumes between 5/7/84 and 5/13/84, during which time the flume 
was being operated in a three-day dilution mode. The Doc concentrations ranged between 4.5 and $11.5 \mathrm{~g} \mathrm{C} \mathrm{m}^{-3}$. At the same time, particulate organic carbon (POC) concentrations varied from $101 \mathrm{~g} \mathrm{C} \mathrm{m}$ immediately after dilution to $687 \mathrm{~g} \mathrm{C} \mathrm{m}^{-3}$ three days later. The average increase in POC during the third day after dilution was $399 \mathrm{~g} \mathrm{C} \mathrm{m}^{-3}$. Clearly such increases in POC could not be accounted for by uptake of DOC if the DOC values never exceeded $11.5 \mathrm{gC} \mathrm{m}^{-3}$. We concluded that the high production observed on the third day after dilution must indeed result from photosynthesis on that day. Table $3-7$ summarizes the temporal trend in POC concentrations in the $48 \mathrm{~m}^{2}$ flume during the threeday dilution cycle experiments. The data are averages from the periods $3 / 26$ to $4 / 19$ and $5 / 16$ to $6 / 2$. The week of heavy rains from $4 / 20$ to $4 / 26$ has been excluded.

Table 3-8 summarizes 1 ipid analyses on platymonas grown in one of the $9.2 \mathrm{~m}^{2}$ flumes from $5 / 7 / 84$ to $5 / 12 / 84$ on a three-day dilution cycle. There was no aramatic change in the lipid content of the algae over the course of the dilution cycle, nor was there much change in the relative amount of neutral and polar lipids. Thus the very high rate of production on the third day after dilution was not associated with any aramatic change in the lipid content of the cells.

Table 3-9 summarizes the results of a small-scale factorial experiment in the $9.2 \mathrm{~m}^{2}$ flumes during April and May to reexamine the relative merit of three and four day dilution cycles and the effect of cell concentration on production. The best results were again obtained with the three-day dilution cycle, and diluting the cell concentration to $2 \times 10^{6}$ cells ml- 1 was preferable to ailuting to $4 \times 10^{6}$ cells $\mathrm{ml}^{-1}$. During this time a careful check was made on the demand for $\mathrm{CO}_{2}$ by the cultures. The combined four flumes consumed one 50 lb. tank of $99.88 \mathrm{CO}_{2}$ in an average time of 7.5 days. Since the average rate of production over this time interval was $0.47(37.9+33.8+29.5+$ $29.4) / 4=15.3 \mathrm{gC} \mathrm{m}^{-2} \mathrm{~d}^{-1}$, the efficiency of $\mathrm{CO}_{2}$ utilization was $(9.2)(4)(15.3)(7.5) /[(50)(454)(12 / 44)]=698$.

Our outdoor flume results with Platymonas can be summarized as follows. By diluting the culture every three days to a concentration of about $2 \times 10^{6}$ cells mil ( $100 \mathrm{gc} \mathrm{m}^{-3}$ ), photosynthetic efficiencies of about 118 can be achieved. These high efficiencies are clearly associated with the establishment of a production rhythm, in which peak production and efficiencies ( 198 ) occur on the third day after dilution. The average

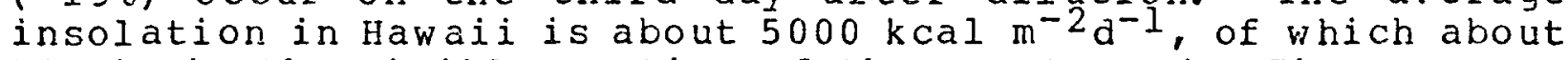
508 is in the visible portion of the spectrum (P. Ekern, pers. comm.). Given the Platymonas energy content of $12.3 \mathrm{kcal} \mathrm{g}^{-1} \mathrm{C}$ and the fact that carbon accounts for 478 of the AFDW of Platymonas, Platymonas production could be expected to average $(5000)(0.5)(0.11) /[(12.3)(0.47)]=47.6 \mathrm{~g} \mathrm{AFDW} \mathrm{m}^{-2} \mathrm{~d}^{-1}$ over the course of a year. Platymonas showed excellent growth throughout the year in our outdoor flumes, and we conclude that this species can grow rapidly at temperatures from approximately $20^{\circ} \mathrm{C}$ to $34^{\circ} \mathrm{C}$. The lower temperature limit of the species is not known at this 
Table 3-7. Mean particulate organic carbon and ash-free dry weight concentrations in the $48 \mathrm{~m}^{2}$ flume during three-day dilution cycle experiments. Units are $\mathrm{g} \mathrm{m}^{-3}$.

Days Since Dilution

POC

AFDW

0

$100 \pm 19$

$213 \pm 40$

1

$224 \pm 24$

$477 \pm 51$

2

$316 \pm 20$

$672 \pm 43$

3

$612 \pm 123$

$1,302 \pm 262$ 
Yalla 3-8. Summary of 1 ipid analyses on Platymonas culture from 19.2 m 2 flumc during three-day dilution cycle. Lipid content cxpressed as of AFDW.

$\begin{array}{lcr}\text { Lipid } & \% \text { neutral } & \% \text { polar } \\ \text { content } & \text { lipids } & \text { lipids }\end{array}$

Days after

dilution

1

2

3
$15.6 \pm 0.5$

$15.0 \pm 0.6$

$17.5 \pm 0.1$
1 ipids

$25.2 \pm 0.8$

$29.4 \pm 0.6$

$26.5 \pm 0.9$
$74.8 \pm 0.8$

$70.6 \pm 0.6$

$73.5 \pm 0.9$ 
Table 3-9. production results from $9.2 \mathrm{~m}^{2}$ flumes operated at a $\mathrm{pH}$ of 7.5 and depth of $10 \mathrm{~cm}$ during April-May, 1984 .

\begin{tabular}{cccc}
$\begin{array}{l}\text { Dilution } \\
\text { Interval } \\
\text { (days) }\end{array}$ & $\begin{array}{c}\text { Cell conc. } \\
\text { just after } \\
\text { dilution } \\
(\text { millions/ml) }\end{array}$ & $\begin{array}{c}\text { Duration } \\
\text { of run } \\
\text { (days) }\end{array}$ & $\begin{array}{c}\text { Daily Production } \\
\left(\mathrm{g} \text { AFDW } \mathrm{m}^{-2}\right)\end{array}$ \\
\hline 3 & 2 & 18 & 37.9 \\
3 & 4 & 18 & 33.8 \\
4 & 2 & 16 & 29.5 \\
4 & 4 & 16 & 29.4
\end{tabular}


time. Over the $20-34^{\circ} \mathrm{C}$ temperature range Platymonas appears to have no significant competitors, and during our study we saw no evidence of predation. Platymonas is capable of excellent growth in salinities as low as $15 \% / 00 ;$ the lower salinity limit of the species is not known at this time. The lipid content of Platymonas equals 15-18\% of the AFDW; $N$ starvation or $N+P$ starvation leads to the accumulation of carbohydrate.

\subsection{EFFORTS TO GROW OTHER SPECIES}

After we had completed the factorial studies with platymonas in the $9.2 \mathrm{~m}^{2}$ flumes, we attempted to carry out similar studies with three other species. Tahitian Isochrysis studies were begun in February. Although we were able to establish dense cultures initially, the flumes were rapidly taken over by Platymonas. Efforts to establish and maintain Isochrysis cultures continued for several weeks into March, but the cultures were invariably taken over by platymonas. In April we attempted to begin a factorial study with a saltwater strain of chlorella which laboratory studies had indicated would grow at $30-34^{\circ} \mathrm{C}$. The result was very similar to the Isochrysis results. Dense initial cultures were established, but the flumes were again taken over by platymonas. We were simply unable to maintain anything resembling unialgal outdoor cultures of either Isochrysis or chlorella for a sufficient period of time to carry out a meaningful factorial study before the cultures become dominated by Platymonas. It is noteworthy here that platymonas grows well in a medium containing a minimum of nutrient additions $(N$, $P$, and trace metals), whereas both Isochrysis and Chlorella required vitamin additions to achieve satisfactory growth. Thus it is impossible to discriminate against platymonas and in favor of some other species by leaving out a particular nutrient, unless of course one is trying to grow a nitrogen-fixing species, in which case $\mathrm{N}$ may obviously be omitted.

In late April we set up a culture of chaetoceros gracilis in a $3 \mathrm{~m}^{2}$ flume which we had originally constructed for hydrodynamic studies with foil arrays. The flume was not designed in an optimai way for microalgae growth, but production appeared to be good, and we began to take samples for particulate carbon analysis on April 30. Over the subsequent three-week period production averaged $35.5 \mathrm{~g}$ AFDW $\mathrm{m}^{-2} \mathrm{~d}^{-1}$, and there was no evidence of Platymonas contamination. Encouraged by these results, we began a factorial experiment in the $9.2 \mathrm{~m}^{2}$ flumes with $c$ gracilis in late May. Unfortunately the flumes were again gradually taken over by platymonas. Since c. gracilis requires additions of both silicate and vitamins, there again is no chance to discriminate against platymonas on the basis of nutrient additions.

In summary, we have been unable to find a species which can effectively compete with Platymonas in an outdoor flume containing a nutrient-enriched seawater medium. This picture may obviously change as we move into studies involving southwestern U.S. water types during the next phase of research. Discrimination against Platymonas on the basis of nutrient 
aditions to seawater is impossible, since Elatymonas itself requires an absolute minimum of nutrient additions. The only exception to this generalization is the $\mathrm{N}$ requirement, where growth of N-fixing blue-green algae would obviously be possible without $N$ additions.

\subsection{TASK III: ANALYSIS OF PROMISING CULTURE MANAGEMENT STRATEGIES}

Objective: 0 To prepare an evaluation of system inputs which quantifies operational parameters and determines the costs and benefits of operating the shallow outdoor flumes with and without temperature controls, in the latter case by substituting thermophilic microalgae for p. tricornutum during the warm months of the year

Purpose: $\quad$ To provide the data required to guide this emerging technology toward effective application

Our experience with Platymonas has indicated that this species can be grown throughout the year in Hawai. Certainly platymonas can be grown successfully at temperatures low enough to permit culture of $P$. tricornutum without temperature control. Thus it is clear that a mass culture system utilizing either platymonas exclusively or Platymonas and . tricornutum could be successfully operated on a year-round basis either in Hawaii or in the southwestern U.S.

The cost of operating a flume mass culture facility similar in design to the system we have been using is estimated in Table 310. The estimated cost of the facility is $\$ 12,401$ per acre-year. If it were necessary to cool the flumes in order to grow $\mathrm{p}$. tricornutum throughout the year, the additional cost would be about $\$ 13,200$ per acre-year (31). Table 3-11 gives a complete breakdown of the materials and energy inputs reguired to produce platymonas.

It is worthwhile at this point to consider the value of the product. If production averages $47.6 \mathrm{~g}$ AFDW $\mathrm{m}^{-2} \mathrm{a}^{-1}$ (i.e. $11 \%$ photosynthetic efficiency in Hawaii), then annual production would be 77.5 tons AFDW per acre-year. If the flumes cover about $80 \%$ of the surface area of the production facility, then the break-even value of the product would have to be $(\$ 12,401) /[(77.5)(2000)(0.8)]=\$ 0.10$ per pound. If we assume the energy content of a barrel of crude oil to be $6 \times 10^{6} \mathrm{BTU}$ (= $\left.1.5 \times 10^{6} \mathrm{Kcal}\right)(33)$, then the microalgal biomass produced in our facility would be cost competitive with crude oil at a crude oil price of $(\$ 0.10)\left(1.5 \times 10^{6}\right) /\left[(0.454)(0.47)\left(12.3 \times 10^{3}\right)\right]=\$ 57$ per barrel. However, if it were necessary to cool the flumes in order to grow P. tricornutum throughout the year, the cost of an equivalent barrel of oil would have to be $(\$ 57)(\$ 12,401+$ $\$ 13,200) /(\$ 12,401)=\$ 118$ per barrel. We conclude that cooling the flumes would more than double the cost of the product, and would make the product uncompetitive with crude oil for the 
Table 3-10. Estimated costs associated with operation of a shallow algal mass culture facility expressed on a per acre-year basis. Estimates based on operation of a 1000 acre facility (33).

I. Total Capital Investment

$\$ 32,450$

II. Direct Costs - nutrients, water, direct labor, maintenance, power, harvesting, and processing

III. Indirect costs - taxes, insurance, depreciation, $\$ 1,645$ land lease

IV. General and Administrative - administration, $\$ 6,187$ interest, return on investment

Total Operating Costs per Acre-year

$\$ 12,401$ 
Table 3-11. Materials and energy inputs required to produce platymonas in shallow outdoor flume. Calculations assume that water is recycled after harvesting cells. Thus nitrogen and phosphorus requirements pertain to nutrients removed with the cells, and water requirements pertain to evaporation losses. Evaporation losses assumed to be $1 \mathrm{~cm}$ per day.

Requirement

$\mathrm{CO}_{2}$

Nitrogen

Phosphorus

Water pumping and mixing

Water
Quantity/kg AFDW

$2.5 \mathrm{~kg}$

$83 \mathrm{~g}$

$11 \mathrm{~g}$

$173 \mathrm{kcal}$

210 liters 
likely foreseeable future. However, if supplemental cooling is eliminated, the cost of an equivalent barrel of crude oil is $\$ 57$, a figure which may well be reached within the next 20 years.

Perhaps the most obvious energy input to the system is the power needed to circulate water through the flumes. The difference in the elevation of water at the high and low point of our $48 \mathrm{~m}^{2}$ fllume is $5 \mathrm{~cm}$. The flow rate is $30 \mathrm{~cm} / \mathrm{sec}$, the water depth is 10 $\mathrm{cm}$, and the width of the flume is $130 \mathrm{~cm}$. Therefore in one second the airlifts must move $(130)(10)(30)=39,000 \mathrm{cc}$ of water a distance of $5 \mathrm{~cm}$. The power input is therefore $(39,000)(5) \mathrm{gm}$ $\mathrm{cm} / \mathrm{sec}=4.57 \mathrm{cal} / \mathrm{sec}=395 \mathrm{Kcal} /$ day. If production averages $47.6 \mathrm{~g} \mathrm{AFDW} \mathrm{m}-2 \mathrm{~d}^{-1}$, the energy output is $(47.6)(0.47)(12.3)(48)=$ $1.32 \times 10^{4} \mathrm{Kcal} / \mathrm{day}$. Hence the energy needed to move the water is $(395)(100) /\left(1.32 \times 10^{4}\right)=3.08$ of the energy output.

Table 3-12 provides a more complete energy balance for the facility (33). The principal energy input is actually the energy required for the nutrients, in particular the energy required for the production of fixed nitrogen. The energy required to operate the airlifts and the energy required for harvesting and processing make up most of the remaining energy inputs. Overall the energy inputs amount to a little less than $24 \%$ of the energy produced in the form of biomass. Thus the energy balance for the facility is quite favorable, at least as long as supplemental cooling is not used to control water temperatures.

In summary, we conclude that the major cost of operating a temperature-controlled shallow flume algal mass culture facility would be the cost of cooling the water. This cost would account for a little over $50 \%$ of the expense of producing the algae. However, if the temperature control constraint is eliminated (e.g. if a species such as platymonas is grown), the biomass produced by the facility would be cost-competitive with crude oil at a crude oil cost of $\$ 57$ per barrel. The major energy inputs to the system would be the energetic cost of producing fixed nitrogen, the energy required to operate the airlifts, and the energy required for harvesting and processing. However, the energy output is estimted to be over four times the energy input. It is noteworthy here that these calculations assume that all the energy content of the product algat is utilized. If only the energy contained in the lipid portion of the cells were utilized, neither the economics nor the energy balance of the project would be favorable. 
Table 3-12. Annual energy balance for shallow algal mass culture system expressed on a per acre water surface areabasis. Estimates based on operation of a 1000 acre facility (33).

Energy Inputs $\left(10^{6} \mathrm{Kcal}\right)$

Materials

General

Nutrients

2.6

68.6

Pumping

Make-up water

0.3

Airlifts

Delivery

11.8

0.7

Piping

0.07

Harvest/Processing

8. 9

Total Energy Input

93.0

Energy of Biomass Produced

393 
4.0 REFERENCES

1. Burk, D., Cornfield, J., and Schwartz, M. 1951. The efficient transformation of light into chemical energy in photosynthesis. Sci. Monthly, 73: 213-223.

2. Clendenning, K. A. and Ehrmantraut, H. C. 1950. Photosynthesis and Hill reactions by whole chlorella cells in continuous and flashing light. Arch. Biochem., 29: $387-403$.

3. Emerson, R. and Arnold, W. 1932a. A separation of the reactions in photosynthesis by means of intermittent light. J. Gen. Physiol., 15: 391-420.

4. Emerson, R. and Arnold, W. 1932b. The photochemical reaction in photosynthesis. Jour. Gen. Physiol., 16:

191-205.

5. Rieke, F.F. and Gaffron, H. 1943. Elash saturation and reaction periods in photosynthesis. J. Phys. Chem., 47: 299-308.

6. Tamiya, H. and Chiba, Y. 1949. Analysis of photosynthetic mechanism by the method of intermittent illumination. Stud. Tokugawa Inst., 6: 1-129.

7. Weller, S. and Franck, J. 1941. Photosynthesis in flashing Iight. J. Phys. Chem., 45: 1359-1373.

8. Falkowski, P.G. and Wirick, C.D. 1981. A simulation model of the effects of vertical mixing on primary productivity. Mar. Biol., 65: 69-75.

9. Kok, B. 1953. Experiments on photosynthesis by chlorella in flashing light, In: Algal Culture from Laboratory to Pilot Plant. Burlew, J.S. (ed) . (Carnegie Inst. of Washington, Washington, DC), Publ. No. 600, pp. 63-75.

10. Kok, B. 1956. Photosynthesis in flashing light. Biochim. Biophys. Acta, 21: 245-258.

11. Markl, H. 1980. Modelling of algal production systems. In: Shelef, G. and Soeder, C.J. (eds). Algae Biomass. ElsevierNorth Holland. Amsterdam. pp. 361-383.

12. Marra, J. 1978a. Effect of short-term variations in light intensj.ty on photosynthesis of a marine phytoplankter: a laboratory simulation study. Mar. Biol. 46: 191-201.

13. Marra, J. 1978b. Phytoplankton photosynthetic response to vertical movement in as mixed layer. Mar. Biol., 46: 203208 . 
14. Phillips, J.N. and Myers, J. 1954. Growth rate of chlorella in flashing light. Plant Physiol., 29: 152-161.

15. Powell, C. K., Chaddock, J. B., and Dixon, J.R. 1965. The motion of algae in turbulent flow. Biotech Bioeng. 7 : 295-308.

16. Sager, J.C., and Giger, W. 1980. Re-evaluation of published data on the relative photosynthetic efficiency of intermittent and continuous light. Agricul. Meteor., 22 : 289-302.

17. Fredrickson, A.G., and Tsuchiya, H. M. 1969. Utilization of the effects of intermittent illumination on photosynthetic microorganisms. In: Prediction and Measurement of photosynthetic productivity, Proceedings of the IBP/PP Technical Meeting, Trebon, September, 1969, (Centre for Agricultural Publications \& Document, Wagenegen, Netherlands). pp. 519-541.

18. Seibert, M., and Lavorel, J. 1982. Oxygen-evolution and patterns from oxygen-evolving photosystem II particles. In: Solar Energy Research Institute Biomass Program Principal Investigators' Review Meeting. Agenda and Abstracts. Washington, D. C., June 23-25, 1982. p. 17.

19. Miller, R. L., Fredrickson, A. G., Brown, A. H., and Tsuchiya, H.M. 1964. Hydromechnical method to increase efficiency of algal photosynthesis. Ind. Engng. Chem. Proces Des. Devel., 3: 134-143.

20. Davis, E.A., Dedrick, J., French, C.S., Milner, H.W., Myers, J., Smith, J. H. C., and Spoehr, H. A. 1953. Laboratory experiments on Chlorelia culture at the Carnegie Institution of Washington department of plant biology. In: Algal Culture from Laboratory to pilot Plant. Burlew, J.S., (ed). Carnegie Inst. of Washington, Washington, D. C. pp. 105-153.

21. Howell, J.A., Fredrickson, A.G., and Tsuchiya, H.M. 1966. optimal and dynamic characteristics of a continuous photosynthetic algal gas exchanger. Chem. Engng. Prog. Symp. Ser. 62(68): 56-58.

22. Oswald, W.J., Golueke, C.G., and Horning, D.0. 1965. closed ecological systems. Proc. Am. Soc. Civ. Engrs. (Sanitary Engineering), 91(SA4): 23-46.

23. Shelef, G., Sabanas, M., and Oswald, W. H. 1968. An improved algatron reactor for photosynthetic life support systems. Proc. 14th Ann. Techn. Meeting Inst. Envir. Sci.

24. Eppley, R.W., R.W. Holmes and J.D.H. Strickland. 1967. Sinking rates of marine phytoplankton measured with a 
Eluorometer. J. Exp. Mar. Biol. Ecol. 1: 191-208.

25. Sharp, J.H. 1974. Improved analysis for "particulate" organic carbon and nitrogen from seawater Limnol. Oceanogr., 19: 984-989.

26. Parsons, T.R., K. Stephens and J.D.H. Strickland. 1961. on the chemical composition of eleven species of marine phytoplankters. J. Fish. Res. Bd. Canada 18: 1001-1016.

27. Strickland, J. D. H. 1958. Solar radiation penetrating the ocean. A review of requirements, data and methods of measurement, with particular reference to photosynthetic productivity. J. Fish. Res. Bd. Canada, 15: 543-493.

28. Milner,H. W. 1953. The Chemical composition of Algae. In: Algal culture: from laboratory to pilot plant. Burlew, J. S. (ed). Carnegie Inst. of Washington, Washington, D. C. chapter 19.

29. Hulbert, E. M. 1982. In: New trends in research and utilization of solar energy through biological systems. Mislin, H., and Bachofen, R. (eds).

30. Thomas, W. H. 1966. Effects of temperature ana illuminance on cell division rates of three species of tropical oceanic phytoplankton. J. Phycol. 2: 17-22.

31. Laws, E.A. 1984. Research, development, and demonstration of algal production raceway (APR) systems for the proauction of hydrocarbon resources. Solar Energy Research Institute subcontract No. XE-0-9013-01 report.

32. Goldman, J. C. 1979. Qutdoor algal mass cultures II. Photosynthetic yield limitations. Water Res. 13: 119136 .

33. Raymond, L.P. 1978. Initial investigations of a shallowlayer algal production system. Hawaii Natural Energy Institute Tech. Rept. No. $7.38 \mathrm{pp}$. 


\section{APPENDIX}

Daily production, AFDW, cell counts, irradiance and photosynthetic efficiencies in $48 \mathrm{~m}^{2}$ flume during January - May, 1984. Photosynthetic efficiencies based on PAR. Double entries

on a given day for culture density and cell counts are values before and after dilution on that day. 
HLY FRODUCTION, ASH-FREE DRY WEIGHTS, CELL COUNTS AWD FHOTOSYNTHETIC E-FICIENCI

\begin{tabular}{|c|c|c|c|c|c|c|c|}
\hline \multicolumn{3}{|c|}{ DTE } & $\begin{array}{l}\text { LIGHY } \\
\text { INTENSITY } \\
\text { (E/mEd) }\end{array}$ & $\begin{array}{l}\text { CULTURE } \\
\text { DENSTTY } \\
\text { (D/ \& AFDW) }\end{array}$ & $\begin{array}{l}\text { CELL. COUNT } \\
(106 \mathrm{mi})\end{array}$ & $\begin{array}{c}\text { PRODUCTION } \\
\text { AFDW } \\
(g / M E d)\end{array}$ & EFFICI \\
\hline 1 & JAN & 84 & 25.907 & .38 & 4.8 & 11.915 & 3.741 \\
\hline$\therefore$ & JAN & 84 & 35.907 & .46 & 4.1 & 12.128 & 3.007 \\
\hline 3 & JFN & 84 & $=5.907$ & .55 & $E .3$ & 19.511 & 5.811 \\
\hline 4 & JAN & 84 & 35.907 & $.6 \theta / .36$ & $E .8 / 3.3$ & 13.617 & 4,275 \\
\hline 5 & JAN & 84 & 35.907 & $.45 / .23$ & $4.5 / 3.0$ & 14.468 & $4.54=$ \\
\hline 6 & JAN & 84 & $=4.88 \mathrm{Z}$ & $=34 / .18$ & $3.3 / 2.3$ & 19.787 & 8.965 \\
\hline 7 & JAN & 84 & 37.100 & $.51 / .17$ & $5,7 / 3.4$ & Ев. $=38$ & 3.597 \\
\hline 0 & JAN & 84 & 37.108 & .42 & 5.9 & 18.936 & 5.753 \\
\hline 3 & JAN & 84 & 37.108 & $.55 / .31$ & $5.7 / 3.7$ & 18.783 & 5.638 \\
\hline () & JAN & 84 & 37.109 & $.4 E$ & 4.5 & $E=.979$ & 6.991 \\
\hline 1 & JAN & $e^{4}$ & 41.134 & $.65 / .30$ & $8.5 / 3.8$ & $1 E .5 \checkmark E$ & 4.543 \\
\hline$\because$ & JAN & 84 & 28.958 & .44 & 5.1 & 25.957 & 10. 105 \\
\hline 3 & JAN & 84 & 39.865 & $.65 / .26$ & E.9/E. & 15.957 & $4.53 \theta$ \\
\hline$: 4$ & JAN & 84 & $20 \times 005$ & $.39 / .14$ & $6.0 / e^{3} 3$ & 18.936 & 7.344 \\
\hline 15 & JAN & 84 & 23,065 & .28 & 4.0 & $12.76 \theta$ & 4.951 \\
\hline$: 6$ & JAN & 84 & 00.055 & $.37 / .19$ & $5.6 / 2=3$ & 11.489 & $4.45 E$ \\
\hline 7 & JGN & 94 & 29.805 & .27 & $=9$ & 26.170 & $10.15 n$ \\
\hline 8 & JAN & 04 & 31.758 & $.47 / .15$ & $7.1 / 1.9$ & 16.2155 & $E .414$ \\
\hline 9 & JAN & E4 & 28.185 & $.2 \theta$ & 4.4 & $\Xi 8.9 \Xi E$ & 15.573 \\
\hline 7 & JAN & 84 & 40.154 & $.59 / .13$ & $6 . \exists / 1.8$ & $= \pm .489$ & 8.033 \\
\hline$\cdot 1$ & JAN & 84 & 30.952 & .29 & 4.7 & $17 . \in E R$ & $0.4 \overline{3}$ \\
\hline$\because$ & JAN & 84 & 30.952 & $.43 / .11$ & $7.5 / 1.6$ & $\Xi 5 . \overline{3} 19$ & Э.ここ1 \\
\hline 3 & JAN & 84 & 35.467 & .30 & 3.7 & $18.5: 1$ & 5.883 \\
\hline$\because 4$ & JFN & 84 & 35.467 & $.44 / .14$ & $E .5 / 1.6$ & 25.313 & 9.048 \\
\hline$\therefore$ & JAN & 04 & 39.983 & .33 & $4=0$ & $=7.0 \geq 1$ & 7. $E: B$ \\
\hline 6 & JAN & 84 & $41.65 \epsilon$ & $.54 / .13$ & $E .7 / 1.5$ & 30.638 & 5. 291 \\
\hline$\therefore 7$ & JAN & 84 & 41.827 & .15 & --- & $31.70 \mathrm{Z}$ & 8.544 \\
\hline$\therefore 9$ & JFN & 84 & 39.683 & .40 & $E, 4$ & $E=128$ & $E . \geq 8 E$ \\
\hline$\because 3$ & JAN & 84 & 39.683 & $.57 / .36$ & B. $2 / 4.1$ & 19.362 & 5.580 \\
\hline 30 & JAN & 84 & 39.511 & $.51 / .47$ & $9.1 / 4.7$ & 8.723 & 2.489 \\
\hline 31 & JAN & 84 & 39.511 & $.53 / .21$ & $10 . \in / 2.5$ & 13.4014 & $3.8 \Xi 4$ \\
\hline 1 & FEE & 84 & 34.790 &.$E 9$ & $5 . \Xi$ & 33.630 & 7.721 \\
\hline$E$ & FEB & 84 & $39.1 \Xi 4$ & $.45 / .20$ & $7.4 / 1.7$ & 8.723 & 2.514 \\
\hline 3 & FEE & 84 & 30.931 & .26 & 3.1 & 27.234 & $9.9 \Xi E$ \\
\hline 4 & $F E B$ & 84 & 34.250 & $.4 \overline{3}$ & 3.1 & 29.574 & 9.734 \\
\hline 5 & $F \subseteq B$ & 84 & 34.250 & $.62 / .27$ & $5.8 / 2.0$ & 18.1255 & $5.9 \Xi 2$ \\
\hline$E$ & FEE & 84 & るこ. 338 & .38 & $E .0$ & 13.191 & 4. $\overline{3} 8 \bar{E}$ \\
\hline 7 & $F E B$ & 84 & 33.938 & $.47 / .20$ & E. $3 / 1.8$ & 21.915 & 7.279 \\
\hline 8 & FEB & 84 & 30.974 & .34 & 3.4 & $E E .170$ & 9.525 \\
\hline 9 & FEE & 84 & 30.738 & $.51 / . \Xi E$ & $5.3 / 1.7$ & $E 4.894$ & 7. $:=44$ \\
\hline 10 & $F E B$ & 84 & $36 . \times 72$ & .37 & 3.9 & $43=404$ & 13.564 \\
\hline 11 & FEE & 84 & 33.497 & $. E E / . E \Xi$ & $E . E / 1 . \theta$ & EQ.95e & 9.758 \\
\hline $1 \Xi$ & FEE & 84 & 31.789 & .40 & 4.6 & 19.574 & $E .342$ \\
\hline 13 & FEE & 84 & 31.789 & $.53 / .90$ & $5.9 / 1.5$ & $25.3 \pm 9$ & 8.979 \\
\hline 14 & FEB & 84 & 34.811 & .29 & 3.8 & 31.064 & $10.0 \div 3$ \\
\hline 15 & $F E B$ & 84 & 30.591 & $.49 / .23$ & $5.0 / 1.9$ & $17 . E \in Q$ & $6.5: 0$ \\
\hline
\end{tabular}




\begin{tabular}{|c|c|c|c|c|c|c|c|}
\hline 16 & $F E E$ & 84 & 35.148 & .37 & 3.9 & 34.843 & $1 \not 1.918$ \\
\hline 17 & FEB & 84 & 31.578 & .64 & E. 4/E. 1 & 51.489 & 18.381 \\
\hline 19 & FEE & 84 & $3 \in .1=8$ & $.87 / .43$ & 5.5 & 36.915 & 11.518 \\
\hline 19 & FEB & 84 & $\Xi E .1 \Xi \theta$ & $.72 / .25$ & B. $6 / \Omega . B$ & EЕ. 34 & 6.971 \\
\hline$\equiv 0$ & FEB & 84 & 39.714 & $.4 E / .1 E$ & 5.1 & 18.830 & 5.345 \\
\hline$\Xi 1$ & FEB & 84 & 39.714 & .30 & $7.9 / 3.5$ & 15.329 & 4. 348 \\
\hline$\Xi 2$ & FEE & 84 & 39.714 & .43 & 5.3 & $37 . \nabla=1$ & 10.583 \\
\hline$E 3$ & FEE & 84 & 38.621 & $.72 / .25$ & 8. $7 /$ Z. 1 & 23.617 & 6.833 \\
\hline 24 & $F E B$ & 84 & 43.844 & .44 & 4.9 & 27.660 & $7.11 \Xi$ \\
\hline 25 & FEE & 84 & $41.2 \pm 7$ & $.6 S / .2 \epsilon$ & $10.8 / 3.2$ & 22.340 & 6.109 \\
\hline$\Xi 6$ & $F E E$ & 84 & $41.2=7$ & .44 & E. 4 & $19.3 \in z$ & 5.294 \\
\hline 27 & FEE & 94 & 45.619 & $.59 / .24$ & $9.4 / 3.1$ & $19.36=$ & 4.784 \\
\hline 28 & FEE & 84 & $4: .557$ & .39 & 5.6 & 49.787 & 13.189 \\
\hline 29 & $F E B$ & 84 & 4.3 .271 & $.78 / .25$ & $9.0 / 2.5$ & $E 5.18 E$ & $E .541$ \\
\hline 1 & MAR & 84 & 39.873 & .45 & 7.1 & 59.574 & 11.189 \\
\hline 2 & MAR & 84 & 38.511 & $.75 / .28$ & 8. $1 / 2.3$ & $\Xi 1 . \Xi 77$ & E. $2 \approx \theta$ \\
\hline 3 & MAR & 84 & 38.643 & .34 & 4.9 & 16.170 & $4.7 \pm 7$ \\
\hline 4 & $M A R$ & 84 & 35.276 & $.47 / . i \epsilon$ & $E .7 / 1.8$ & $\Xi 8.851$ & $E .6 E \Xi$ \\
\hline 5 & MARR & 84 & 43.544 & $.3 E$ & $\Xi .8$ & 33.830 & 8.758 \\
\hline$\epsilon$ & MAR & 84 & 43.544 & $.58 / .20$ & $7.4 / \Xi .1$ & 3E. TEE & 8.483 \\
\hline 7 & MAR & 84 & 42.731 & .46 & 5.2 & 49.511 & $1 \Xi .798$ \\
\hline$B$ & MAR & 84 & 42.731 & $.84 / .27$ & $210.5 / 3.3$ & 25.745 & 6.792 \\
\hline 9 & MAR & 84 & 43.869 & .47 & 7.7 & 45.319 & 11.646 \\
\hline 10 & MAR & 84 & 43.581 & $.8 \Xi / .24$ & $11.6 / 3.8$ & $E 7 . E E \varnothing$ & 7.155 \\
\hline 11 & $M A R$ & 84 & 42.691 & .45 & $E .5$ & $27.6 E \phi$ & 7.384 \\
\hline 13 & MAR & 84 & 48.714 & $.6 B / .37$ & 7.013 .3 & 18. 278 & 4. 234 \\
\hline $1 \overline{3}$ & MAR & 84 & 50.278 & .52 & 7.1 & 50.851 & $11: 481$ \\
\hline 14 & MAR & 84 & 53.004 & $.91 / .28$ & $12 . \Xi / 3.4$ & 24.255 & 5.157 \\
\hline 15 & MAR & 84 & 44.745 & .47 & $7 \cdot 1$ & コこ. $1 \Xi 9$ & S. 094 \\
\hline$I E$ & MAR & 84 & 44.988 & $.72 / .14$ & $8.5 / 3.0$ & $\Xi 6.170$ & E. 558 \\
\hline 17 & MAR & 84 & 44.988 & .34 & 7.8 & $\Xi 6.170$ & 6.558 \\
\hline 18 & MifiR & 84 & 44.988 & $.55 / .28$ & $E .6 / \Xi .2$ & $\Xi 0.253$ & 5. RIES \\
\hline 19 & MAR & 84 & 54.269 & .44 & 5.9 & 20.851 & 4. 331 \\
\hline 20 & MAR & 84 & 58.801 & $.60 / .09$ & $7.2 / 3.1$ & $1 E .170$ & 3.143 \\
\hline 21 & MAR & 84 & 53.0203 & .41 & 5.0 & 10.851 & 2. 308 \\
\hline 2 & MAR & 84 & 53.0003 & $.50 / .27$ & 4. $9 / \Xi . \Xi$ & $\Xi 0.4 E \epsilon$ & 4.344 \\
\hline 23 & MAR & 84 & 55.427 & .43 & 5.1 & 20.020 & 4. $\square \in 8$ \\
\hline 24 & MAR & 84 & 44.951 & $.59 / .34$ & E. 7/E. 7 & $\Xi 7.87 \Xi$ & $E .99 \square$ \\
\hline 25 & MAR & 84 & 50.284 & $.4 E$ & 5.2 & $7 \varepsilon .170$ & $17.07 \varepsilon$ \\
\hline$E E$ & MAR & 84 & 48.771 & $1.25 / .29$ & $3.1 / 1.8$ & 29.787 & 6.885 \\
\hline 27 & MAR & 84 & 48. $\Xi \in 3$ & .41 & 4.4 & 27.234 & $6.3 E 1$ \\
\hline$E \theta$ & $M_{i} A R$ & 84 & 39.468 & $.6 \Xi$ & 7.3 & 91.915 & $E \varepsilon . E \Xi 3$ \\
\hline 29 & MAR & 84 & $40.5 \in \Xi$ & $1.34 / . \Xi \Xi$ & $11.7 / 1 . \epsilon$ & 35.319 & $9.81 E$ \\
\hline 30 & MAR & 84 & 41.656 & .49 & 5.6 & 28.085 & 7.600 \\
\hline 31 & MAR & 84 & 41.656 & .71 & 13.7 & 93.191 & 25.229 \\
\hline 1 & AFr & 84 & 47. $27 \epsilon$ & $1.43 / .23$ & $15.2 / 1.7$ & 34.1843 & 8. $1: 7$ \\
\hline 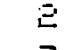 & $A F^{\prime} R$ & 84 & 53.496 & .49 & $5 . \emptyset$ & 30.000 & $6.3 E=$ \\
\hline 3 & AF'R & 84 & 49.587 & $.7 \overline{3}$ & 9.9 & $1 \Xi \overline{3} .6: 7$ & E'E. 148 \\
\hline 4 & AF'R & 84 & 51.074 & $1.69 / .20$ & $17.1 /$ E. 1 & ZE. 829 & 8. $1 \Xi \pm$ \\
\hline 5 & AF'R & 84 & 4E. IEQ & .49 & 6.9 & 27.812 & 6.539 \\
\hline$E$ & AF'R & 84 & 44.058 & .72 & 8. 3 & 90.020 & $\Xi \Xi . \Delta \Xi 8$ \\
\hline 7 & $A F R$ & 84 & 48.434 & $1.4 \emptyset / \Xi . \nabla$ & $25.8 / 1.7$ & 27.021 & ย. こ89 \\
\hline 8 & APR & 84 & 48.477 & .42 & 7.0 & 28.723 & 6.679 \\
\hline 9 & AF'R & 84 & 43.496 & .64 & 7.0 & 56.170 & 24.925 \\
\hline 10 & AF̈R & 84 & 48.434 & $1.39 / .14$ & $14.9 / 1.4$ & 44. 255 & 10.320 \\
\hline
\end{tabular}




\begin{tabular}{|c|c|c|}
\hline 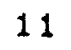 & HFR & \\
\hline & $A F A$ & \\
\hline & $A F R$ & \\
\hline & $A \cap R$ & \\
\hline & $A F R$ & \\
\hline & $A F^{\prime} R$ & \\
\hline & $A F R$ & \\
\hline & $A F R$ & \\
\hline & $A F R$ & \\
\hline & $A F R$ & \\
\hline & $A F R$ & \\
\hline & AFR & \\
\hline & $A R R$ & \\
\hline & AFR & \\
\hline & $A A^{\prime} R$ & \\
\hline$\epsilon$ & $A P R$ & \\
\hline & $A F R$ & \\
\hline & AFR & \\
\hline & $A=R$ & \\
\hline & APR & \\
\hline 1 & MAY & \\
\hline $\mathrm{Z}$ & MAY & \\
\hline 3 & MAY & \\
\hline 4 & MAY & 34 \\
\hline 5 & MAY & 94 \\
\hline$E$ & MAY & 3. \\
\hline 7 & MAY & 34 \\
\hline$\theta$ & MAY & 36 \\
\hline 9 & MAY & . \\
\hline 10 & MAY & 8 \\
\hline 1 & MAY & 8 \\
\hline$\Xi$ & MaY & 8 \\
\hline 3 & MAY & $\theta$ \\
\hline 4 & MAY & 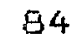 \\
\hline 15 & MAY & 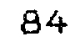 \\
\hline $1 E$ & $M_{A} A Y$ & 8 \\
\hline 17 & MAY & 8 \\
\hline $1 B$ & MAY & 8 \\
\hline 19 & MAY & 8 \\
\hline 20 & MAY & 8 \\
\hline 1 & MAY & 84 \\
\hline $2 \Xi$ & MAY & . \\
\hline 23 & MAY & 8 \\
\hline 24 & MAY & 84 \\
\hline 25 & MAY & 94 \\
\hline $2 E$ & MAY & \\
\hline 27 & MPY & \\
\hline 28 & MAY & \\
\hline$\Xi 9$ & MAY & \\
\hline 30 & MAY & \\
\hline & & \\
\hline
\end{tabular}

\begin{tabular}{|c|c|}
\hline 51.437 & .49 \\
\hline 53.325 & .64 \\
\hline 50.432 & $1.50 / .16$ \\
\hline 51.394 & .41 \\
\hline $50.4 こ 9$ &.$E 8$ \\
\hline 50.937 & $.88 / .29$ \\
\hline 50.997 & .51 \\
\hline 51.565 & .72 \\
\hline 56.872 & $1 . E R / .16$ \\
\hline $4 \Xi .1 \Xi 8$ & $.27 / .12$ \\
\hline $4 E .1284$ & .56 \\
\hline 58.763 & .70 \\
\hline 48. 263 & $.89 / .25$ \\
\hline 58.004 & .47 \\
\hline 48.391 & .58 \\
\hline 31.489 & $.64 / .18$ \\
\hline 43.734 & .36 \\
\hline 50.836 & .72 \\
\hline 50.836 & 1. DE \\
\hline 58.044 & $1.01 / .29$ \\
\hline 56.971 & $.4 \mathrm{E}$ \\
\hline 39.983 & .64 \\
\hline 49.817 & .92 \\
\hline 48.734 & $1.19 / .21$ \\
\hline 59.116 & .48 \\
\hline $44.4 \square 2$ & .82 \\
\hline 66.409 & $.9 E$ \\
\hline 55.212 & $1.15 / .23$ \\
\hline 45.559 & $.4 E$ \\
\hline 58.144 & .70 \\
\hline 61.2046 & .98 \\
\hline 29.515 & $.85 / .=9$ \\
\hline $60.74 E$ & .53 \\
\hline 65.208 & .73 \\
\hline 55.770 & .95 \\
\hline 52.810 & $1.44 / .19$ \\
\hline 57.958 & .44 \\
\hline 56.843 & .64 \\
\hline 58.148 & $.87 / .20$ \\
\hline 58.149 & .42 \\
\hline 57.454 & .59 \\
\hline 47.506 & 1.ฤ3/.Eこ \\
\hline 64.135 & .49 \\
\hline 5อ. 424 & .64 \\
\hline 38.438 & 1. $05 / .23$ \\
\hline 55.598 & .50 \\
\hline 53.539 & .70 \\
\hline 59.145 & 1. $\Xi E / . Z 4$ \\
\hline 57.443 & .55 \\
\hline 49.286 & .70 \\
\hline 53.797 & $1.5 \pi / .27$ \\
\hline
\end{tabular}

\begin{tabular}{|c|c|c|}
\hline 6. 4 & 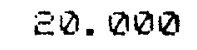 & 4.383 \\
\hline 9.9 & 104.468 & 22. 1785 \\
\hline $13.4 / 1.3$ & 3อ. 128 & 7. 181 \\
\hline 5.2 & 34.681 & 7. $6 \otimes 7$ \\
\hline 9.8 & 26.170 & 5.850 \\
\hline $10.7 / 2.6$ & 28.936 & E. 336 \\
\hline 5.9 & 27. ถこ1 & 5.973 \\
\hline 3.0 & $1=0.638$ & 26.373 \\
\hline $15.5 / 1.6$ & $14.4 E \theta$ & 2. 868 \\
\hline$=.8 / 1.0$ & 56.809 & 15. $2 \nabla 1$ \\
\hline 4.2 & 18.936 & 5.072 \\
\hline 10.8 & 23.404 & 4.490 \\
\hline $10.0 / 2.5$ & 31.277 & 7. 305 \\
\hline 6.7 & 11.277 & 2. 190 \\
\hline 7.2 & 7.872 & 1.834 \\
\hline $8.8 / 1.6$ & 23.830 & 8. 531 \\
\hline 4.1 & 44.854 & 18.385 \\
\hline & 44.894 & 3.955 \\
\hline 14.3 & $-E .596$ & $-1.4 \in 3$ \\
\hline $14.5 / 2.4$ & 17.821 & 3. $3 \nabla E$ \\
\hline 5.8 & 28.936 & 5.726 \\
\hline 8.7 & 35.319 & 9.958 \\
\hline 12.8 & 35.532 & 8.040 \\
\hline $15 . E / 1.8$ & 34.681 & 8. ถேこ \\
\hline E. 8 & 42.766 & 8.155 \\
\hline 10.9 & 18.936 & $4.88: 8$ \\
\hline $1 \Xi .4$ & 23.4274 & 3.973 \\
\hline--- & 24.255 & 4. $9=E$ \\
\hline$-\ldots$ & 35.319 & 8.739 \\
\hline 8.9 & 35.957 & 6.983 \\
\hline 10.9 & $-17.0 \geq 1$ & -3.143 \\
\hline $9 . \overline{3} こ . \emptyset$ & 31.064 & $11.8 E 5$ \\
\hline 5.6 & $\Xi 6.170$ & 4.957 \\
\hline 5.8 & 28.208 & 4. $8 \exists=$ \\
\hline 10.4 & $E \pm .7 E E$ & 1Е.Eघ7 \\
\hline $17.5 / 2.5$ & 32.553 & $E .949$ \\
\hline 5.9 & Е5. 106 & 4.883 \\
\hline 7.9 & 29.787 & 5.907 \\
\hline $13.3 / 2.3$ & 27.234 & $5 . \pm 80$ \\
\hline 4.2 & ㄹ․ 128 & 4. 250 \\
\hline 4.9 & 55.957 & 10.610 \\
\hline $18.9 / 2.3$ & 34.681 & 7.897 \\
\hline 5.6 & 17.574 & 3.441 \\
\hline 8.1 & 52.340 & 11.255 \\
\hline $1 \Xi .9 / 2.6$ & 33.617 & 9.859 \\
\hline 5.7 & $\approx 6.170$ & 5.386 \\
\hline 8.4 & 67.034 & 14.157 \\
\hline $14.5 / 2.8$ & 39.574 & 7.543 \\
\hline 7. $\Xi$ & $\Xi 0 . \nabla \nabla \nabla$. & $3.5 E 5$ \\
\hline$: 0.7$ & $1 \nabla 2.1 E 8$ & 23.397 \\
\hline $14.8 / 2.4$ & 37.600 & 7.891 \\
\hline
\end{tabular}




\begin{tabular}{|c|c|c|}
\hline $\begin{array}{l}\text { Document Control } \\
\text { Page }\end{array}$ & \begin{tabular}{|l|l|} 
1. SERI Report No. & 2. NTIS Accession No. \\
SERI/STR-23]-2496 &
\end{tabular} & 3. Recipient's Accession No. \\
\hline \multirow{2}{*}{\multicolumn{2}{|c|}{$\begin{array}{l}\text { 4. Title and Subtitle } \\
\text { Research and Development of Shallow Algal Mass } \\
\text { Culture Systems for the Production of } 0 i 1 \mathrm{~s}\end{array}$}} & $\begin{array}{r}\text { 5. Publication Date } \\
\text { October } 1984 \\
\end{array}$ \\
\hline & & 6. \\
\hline $\begin{array}{l}\text { 7. Author(s) } \\
\text { Edward A. Law }\end{array}$ & & 8. Performing Organization Rept. No. \\
\hline \multirow{2}{*}{\multicolumn{2}{|c|}{$\begin{array}{l}\text { 9. Performing Organization Name and Address } \\
\text { University of Hawa i } i \\
\text { Honolulu, Hawa } i j\end{array}$}} & $\begin{array}{l}\text { 10. Project/Task/Work Unit No. } \\
4625.10\end{array}$ \\
\hline & & $\begin{array}{l}\text { 11. Contract (C) or Grant (G) No. } \\
\text { (C) } X K-3-03136-1 \\
\text { (G) }\end{array}$ \\
\hline \multirow{2}{*}{\multicolumn{2}{|c|}{$\begin{array}{l}\text { 12. Sponsoring Organization Name and Address } \\
\text { Sol ar Energy Research Institute } \\
1617 \text { Cole Boulevard } \\
\text { Golden, Colorado } 80401\end{array}$}} & $\begin{array}{l}\text { 13. Type of Report \& Period Covered } \\
\text { Technical Subcontract } \\
\text { Report }\end{array}$ \\
\hline & & 14. \\
\hline \multicolumn{3}{|l|}{ 15. Supplementary Notes } \\
\hline \multicolumn{3}{|c|}{$\begin{array}{l}\text { 16. Abstract (Limit: } 200 \text { words) } \\
\text { The major accomplishment of the past nine months' work was the identification } \\
\text { of a microalgal species which can be grown in the system on a } 12 \text {-month basis } \\
\text { without temperature control. The most promising species identified to date is } \\
\text { a strain of platymonas sp. This strain grows rapidly at temperatures from } 20^{\circ} \\
\text { to } 34^{\circ} \mathrm{C} \text {, and at salinities from } 15 \mathrm{~g} 35 \% \text { oo. Neither the lower temperature } \\
\text { limit nor the lower salinity } 1 \text { imit of the strain are known at this time. A } \\
\text { factorial experiment designed to determine optimum growth conditions indicated } \\
\text { that the optimum culture depth was } 10 \mathrm{~cm} \text {, the optimum pH about } 7.5 \text { and the } \\
\text { optimum flow rate about } 30 \mathrm{~cm} / \mathrm{s} \text {. A major discovery was that diluting the } \\
\text { culture every third day greatly enhanced production. In this dilution mode } \\
\text { daily yields averaged } 46 \mathrm{~g} / \mathrm{m}^{2} \text { ash-free dry weight (AFDW) over a one-month } \\
\text { period, and photosynthetic efficiencies averaged } 11 \% \text { (based on visible } 1 \text { ight } \\
\text { energy). The former figure is over twice the best long-term yields achieved } \\
\text { in microalgal mass culture systems grown exclusively on inorganic nutrients. }\end{array}$} \\
\hline \multirow{2}{*}{\multicolumn{3}{|c|}{$\begin{array}{l}\text { 17. Document Analysis } \\
\text { a. Descriptors Algae; Chlorella; Cost; Efficiency; Productivity; Seawater; } \\
\text { Unicellular Algae } \\
\text { b. Identifiers/Open-Ended Terms Chaetoceros Gracilis; Isochrysis; Platymonas }\end{array}$}} \\
\hline & & \\
\hline \multirow{2}{*}{\multicolumn{2}{|c|}{$\begin{array}{l}\text { 18. Availability Statement } \\
\text { National Technical Information Service } \\
\text { U.S. Department of Commerce } \\
5285 \text { Port Royal Road } \\
\text { Springfield, Virginia } 22167\end{array}$}} & $\begin{array}{c}\text { 19. No. of Pages } \\
57\end{array}$ \\
\hline & & $\begin{array}{r}\text { 20. Price } \\
\text { A04 }\end{array}$ \\
\hline
\end{tabular}

